\author{
SCENTIA INTERNATIONAL ECONOMIC REVIEW \\ Volume 1 - Issue 2 - 2021
}

\title{
Leadership Sentiment and Oil Price Fluctuations
}

\author{
Tim Herzhoff, Mendel University, Brno, Czech Republic \\ Thomas Teichert, Mendel University, Brno, Czech Republic
}

\begin{abstract}
The relationship between prices and leadership mood was examined using the example of crude oil prices and the sentiment of the CEOs of 5 leading oil production companies between 2014 and 2019. The crude oil market was chosen due to recent price fluctuations and upcoming challenges, and for its significant for the global economy.

This study uses an empirical approach based on a mood analysis of the CEO's natural language. 160 speech transcripts were analyzed using a leading aspect-based sentiment analysis machine learning algorithm to obtain sentiment data. The relation between sentiment and oil price was tested using linear regression. The results of this study show in detail that the sentiment correlates positively in times of low prices and negatively in times of high prices. The average threshold price calculated using this method was 63 USD per barrel of West Texas Intermediate (WTI) crude oil in the observed period. This corresponds to analysts who estimated the ideal oil price for 2018 at USD 60 to 70. Finally, the restrictions and prospects are discussed. Findings of this study could aid investors decision making and advance the use of sentiment analysis in economic sciences.
\end{abstract}

Keywords: Sentiment Analysis; Machine Learning; Leadership Sentiment; Oil Price Plunge

JEL codes: A100, A110 


\section{Introduction}

\subsection{Leadership Challenges in Oil and Gas}

Why research the relationship between market fluctuations and leadership sentiment, based on the oil and gas market? There is a practical demand for it.

Crude Oil is commonly known to be the most traded commodity in the world, with many other parts of the economy currently dependent on pricing of petroleum products. For instance, studies have found a positive relationship between oil prices and food prices (Chen, Kuo, \& Chen, 2010) (Gohin \& Chantret, 2010). Other studies, since the 1980s, observed that changes in oil price can affect US dollar exchange rates and interest rates (Golub, 1983) (Amano \& Van Norden, 1998) (Lutz \& Zhou, 2019). Other aspects of the economy are influenced as well, such as container ship fleet size and the optimum speed at which ships transport goods (Ronen, 2011).

Even though large parts of the economy currently depend on the oil industry, leaders of oil-producing companies face major mid- and long-term challenges. Some of those challenges include a Changing , a Shrinking Demand for Oil, and the "Race to Sell Oil".

\subsubsection{Changing Market}

With advances in technology, unconventional sources of energy such as biofuels, oil sands, and shale become profitable. (See Figure 1)

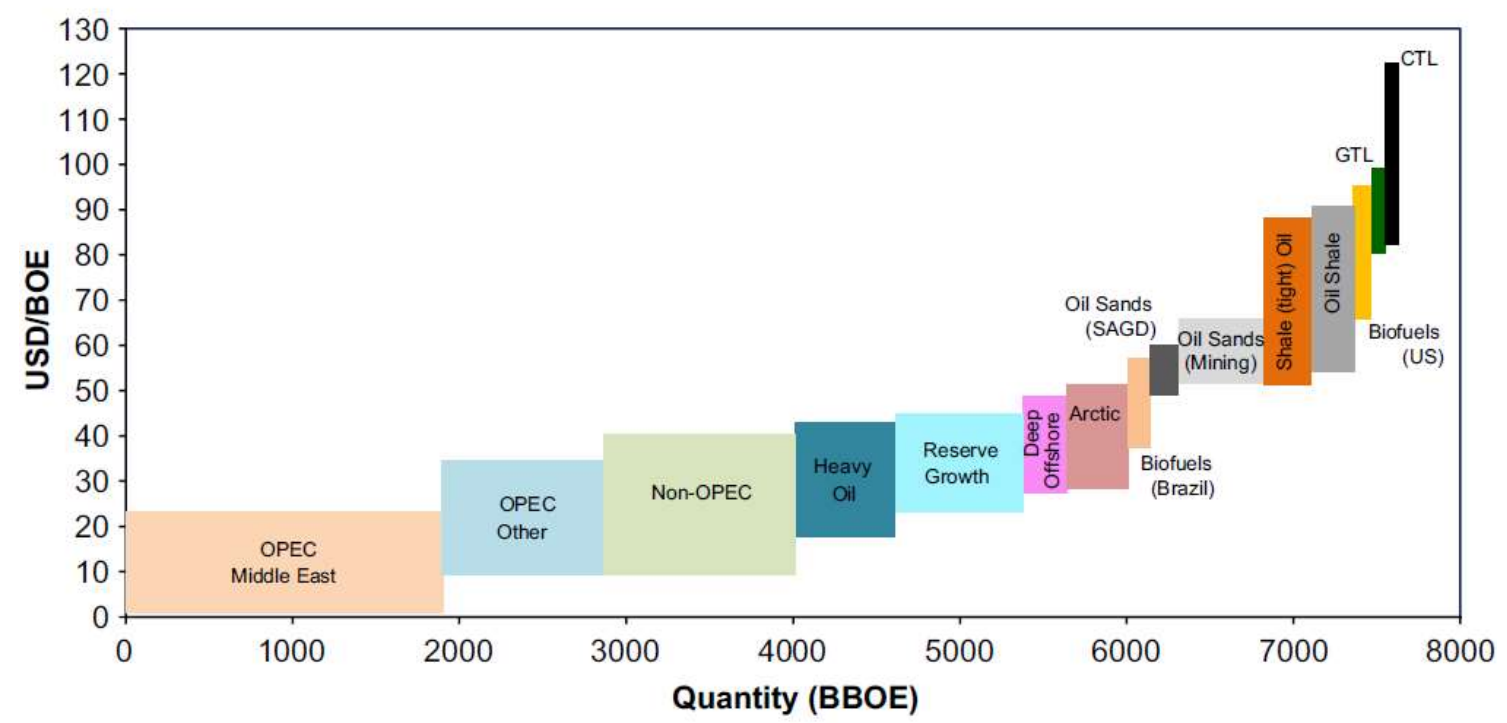

Figure 1 - Oil supply production costs versus recoverable quantities. (Aquilera, 2014) p. 138

With oil prices hovering around the 100 USD mark as it was last seen before the 2014 shale oil boom many unconventional oil production methods are profitable. 
This in turn can lead to market disruptions triggered by supply driven price dumps which reduce the profit margins with significant impact on balance sheets and company valuation across the industry. On the other hand, with many reserves maturing these alternative production methods may be needed to accommodate possible increases of demand in future scenarios. Demand side increases seem unlikely in current times but especially in sectors like shipping, transportation, and chemicals oil can hardly be substituted entirely with existing technologies.

"As alternative energy sources make inroads, energy efficiency improves, and with today's moderate oil demand growth, the longer-term oil outlook is fairly healthy. Despite some marvelous advancement by various hybrids and pure electrics, petroleum-based liquids will remain the fuels of choice, holding between 80 and 90 percent of transport market share in 2050 depending on the scenario considered." Khalid A. Al-Falih, CEO of Saudi Aramco 2014-08-25 (Saudi Aramco, 2015)

The steady increase in global population may someday lead to reliance on unconventional methods to supply for applications where alternatives to combustible fuels do not exist from a technological or economic standpoint. This shift will likely not occur over night but some of the major oil companies keep unconventional methods in their portfolios to prepare for such a scenario.

"[Shell] is planning for a longer period of low prices. But for the longer term, as I've said on several occasions in the recent past, I see no change to fundamental drivers of oil markets. There will be more people on this planet; more people living in cities; and more people buying their first car or refrigerator. As a result, demand for energy - including demand for oil - is likely to grow. In turn, higher demand will need new supplies. These supplies won't be cheap to produce." - Ben van Beurden, CEO of Shell MORE OIL, LESS MONEY 2015-10-06 (Shell, 2015)

Securing expertise and access to unconventional sources could one day be the difference between leaving market share to other market participants or displacing new market entrants. The shale boom has demonstrated how eager market participants quickly fill and defend any potential market gaps.

"The shale revolution in the US offers the most recent compelling example of a sector-wide transformation, as costs were reduced, and technology adapted and optimized to make a previously uneconomic resource viable. The resulting production volumes speak for themselves." - Khalid A. Al-Falih, CEO of Saudi Aramco 2014-0825 (Saudi Aramco, 2015)

After all, with the many non-technical uncertainties to be considered it remains unclear if or when today's strategic investments in unconventional oil production will pay off.

\subsubsection{Shrinking Demand for Oil}

In recent years, the price of oil has been subject to fluctuations. From mid-2014, the price of Brent crude oil dropped by $60 \%$ within half a year. (Fantazzini, 2016). Since January 2016 the price of crude oil is increasing again. Meanwhile, leaders of the oil 
and gas industry, such as the CEO of Shell, Ben van Beurden, realized that demand for crude oil could reach its peak as early as the 2020s or 2030s. (CNBC, 2017). The costs of battery production, wind energy and renewable energy is decreasing quickly (Fortune Media IP Limited., 2018). Important demand sectors, such as transportation are becoming largely electrified, which could leave big oil companies with "stranded assets" if they do not adjust to upcoming changes (Van de Graaf, 2018).

Although the oil market exerts a great impact on the rest of the economy, the rest of the economy exerts a great impact on the oil industry. Due to a viral outbreak at the end of 2019, economic activities were affected on a global scale. Oil supply could not adapt to the comparatively quick reduction in demand for petroleum products. This imbalance led to an unavailability of oil storage. Consequently, crude oil future contracts were, for the first time in history, trading for less than 0 USD per barrel, which is illustrated in Figure 2.

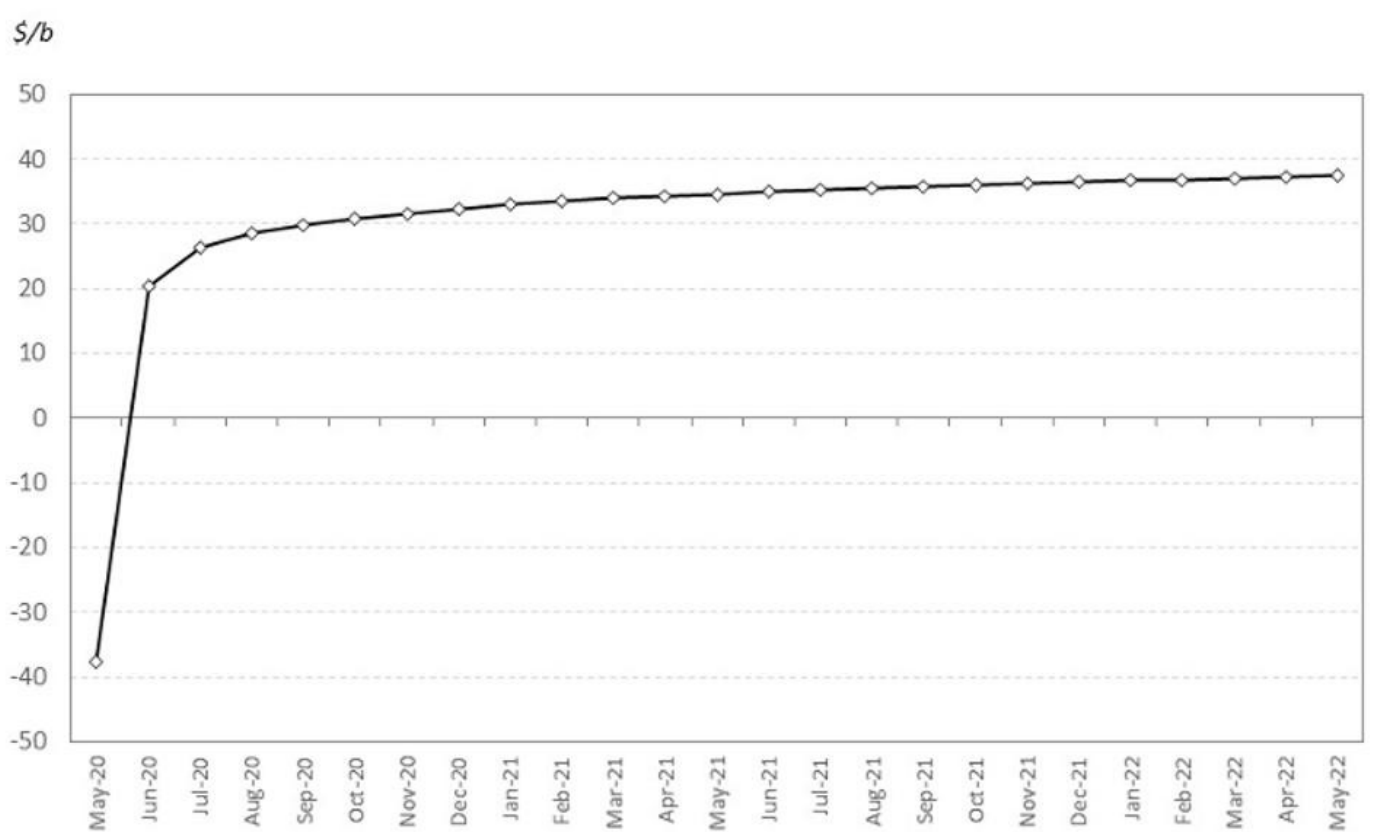

Figure 2 - On April 20, 2020 WTI future contracts for May traded for less than 0 USD on the CME (Chicago Mercantile Exchange). (Medlock III, 2020)

This practical example shows how sensitively the oil market can react to a shrinking demand for petroleum products in the rest of the economy. It also demonstrates that the high demand for petroleum products in recent years cannot necessarily be taken for granted in future decades. 


\subsubsection{Race to Sell Oil}

In previous decades an oil owner had to find the optimal extraction strategy between leaving oil in the ground for later extraction at higher profit and extracting now with returns being invested in the financial market (Hotelling, 1931). In the face of diminishing oil demand and possible restrictions on oil extraction and consumption the premise has changed. It has been argued that oil can no longer be left in the ground as an asset for future extraction, but rather a "race to sell oil" despite lower profitability could become the dominant strategy (Van de Graaf, 2018). This development may contribute to narrower margins for oil producers and pose a challenge for leaders in this industry.

\subsubsection{Other Factors}

Granted, the above-mentioned themes provide a glimpse into the challenges that leadership in the oil and gas industry must consider. There are, however, many more factors that cannot be exhaustively discussed, but play a significant role to the industry, nonetheless. Some of them fall into the following categories:

- Geopolitical factors that impact the oil industry directly or indirectly by influencing the global economic activity (Cunado, Gupta, Marco Lau, \& Sheng, 2020).

- Changes in consumer technology and behavior. Growing energy demand in emerging markets. (Kabundi \& Ohnsorge, 2020)

- Long-term production trends, such as the continuous maturing of existing oil reserves or technological innovation in extraction.

\subsection{Leadership Sentiment}

Given the fluctuations in oil prices and the current and upcoming economic challenges for oil producers, equity and commodity investors are interested in how oil and gas market leaders assess the market situation. However, investors can only base their buying, selling, or holding decisions on the limited publicly available information. That is why analysts and investors listen to oil and gas CEOs' speeches, and factor in the quantitative and qualitative information that these speeches contain. 


\subsubsection{Relationship Between CEO Sentiment and Investor Sentiment}

A psychology study researched the relationship between the mood of followers and the mood of the leader. This study has found a positive correlation between the mood of leaders and mood of followers (Sy, Côté, \& Saavedra, 2005). The study examined the relationship between managers and employees. These findings suggest that the mood of investors and the mood of CEOs behave similarly if the results of the study can be expanded to the relation between investors and CEOs.

Other researchers, which focused on stock pricing, found manager sentiment to similar to investor sentiment in a given timeframe. The researchers explained, that wellinformed managers tend to be subject to emotions comparable to those of investors (Jiang, et al., 2016). These findings confirm a general relationship between investors sentiment and CEO sentiment.

A study focusing on German CEOs' speeches during the Annual General Meeting found that the CEOs speeches have a significant impact on trading volumes, even if the speeches are preceded by several information disclosures. According to this research, positive speech sentiment is positively associated with abnormal stock returns (Bannier, Pauls, \& Walter, 2017). This suggests that the CEO speeches contain price relevant sentiment information, which is not available from the company's financial reports.

\subsubsection{Relationship between Investor Sentiment and Market Pricing}

Other research suggests that the impact of investor sentiment on the stock market is measurable, with hard to arbitrage stocks being the most affected. (Baker \& Wurgler, Investor sentiment in the stock market., 2007) Using proxies to measure sentiment, two studies showed that investor sentiment has a significant influence on the crude oil price, in addition to other economic influences (Qadan \& Nama, 2018) (Du, Gunderson, \& Zhao, 2016). Vice versa, another study (Apergis, Cooray, \& Ur Rehman, 2018) has shown that oil price "exerted a negative impact on investor sentiment" (p. 139).

\subsubsection{Investor Sentiment Index}

Researchers developed several investor sentiment indexes using various paradigms and approaches: 
A survey-based investor sentiment index derived from the bull-bear spread of investment newsletters was proposed. The classification of bullish newsletters and bearish newsletters was done manually (Brown, et al., 2005).

Baker and Wurgler published their investor sentiment index based on three proxies (Baker, Wurgler, \& Yuan, Global, local, and contagious investor sentiment, 2012):

- Volatility premium (PVOL), which is the logarithmic ratio of the weighted average market-to-book ratio of high and low volatility stocks.

- The total volume of initial public offerings (IPO).

- Initial first day returns of these IPOs

Insights from Baker and Wurgler's investor sentiment research were used to eliminate noise components in another sentiment index focusing on price prediction (Huang, Jiang, Tu, \& Zhou, 2015).

The authors in these three examples have demonstrated that their sentiment index is significant in predicting prices.

\subsubsection{Manager Sentiment Index}

Existing research has also focused on developing an index for management sentiment. One notable example is using aggregated textual tone in financial disclosures. Textual tone was measured with word count of positive and negative words using a standard dictionary method. This study found that textual tone negatively predicts stock market returns (Jiang, et al., 2016). The author shows that although CEO sentiment and investor sentiment are positively associated, there is additional unique information contained in CEO sentiment, which is not reflected in investor sentiment indexes.

While the common methods to determine sentiment are proven in use, such as the dictionary and word counting method, the chosen methodology of these indexes is not without limitation. A recurring limitation in the mentioned sentiment indexes is the non-specificity of the sentiment measurement. These indexes are widely used to measure sentiment on the global economy or that of large national economy. However, the methods used in the given examples do not support aspect-based sentiment measurement. In theory, these indexes may be adaptable to measure sentiment associated with a market (e.g. financial service, energy) by only analyzing the sentiment of companies that are active in this market. However, some of the companies may be active in multiple markets, which could result in cross interference. In contrast, when using aspect-based sentiment analysis, it should be possible to effectively avoid cross interferences. Using aspect-based sentiment analysis should also enable effective measurement of sentiment associated with a submarket (e.g. home 
loans, pension plans, crude oil, coal), product class (e.g. 401(k), Brent oil), or sentiment associated with a business thread or opportunity like climate change or equality.

A study used empirical research to examine the impact of executives' apologies in speeches on investors. The study found, that investors favor an ethically sound apology by a CEO, who apologizes for specific wrongdoings, instead of offering a broad and general apology (Daryl \& Goranova, 2018). In addition to other studies, which show that investor sentiment is influenced by CEO sentiment, the results of this study suggest that investors differentiate between general expressed sentiment of CEOs and sentiment associated with specific aspects of the CEO's speech. If that is the case, then the use of aspect-based sentiment analysis (ABSA) over other methods would be worthwhile, when analyzing the natural language data of CEO speeches, because this method would be more analogous to how actual investors "analyze" the sentiment of a CEO. 


\section{Objectives}

\subsection{Intended Contribution of This Study to Research}

This study closes the above-mentioned gaps in research and could raise new research questions.

Aspect Based Sentiment Analysis (ABSA) is frequently used in commercial applications, but not often in research. This study could encourage the use of ABSA for science.

\subsection{Intended Contribution of This Study to Practical Applications}

The method used in this study could help companies to verify sentiment representation in executive speeches.

Analysts rely on publicly available information for determining pricing of stocks and commodities. Analysts may use this method to quantify and compare the price sensitive sentiment information of companies in a more effective and objective way. Additionally, as this method relies on speech transcripts, this aspect of price analysis can potentially be automated.

\subsection{Research Question}

This study aims to contribute to economic research and specific practical applications as outlined in paragraphs 2.1 and 2.2. Therefore, the following research question was formulated with the aim to satisfy the intended contributions.

What effect does the price of oil have on the sentiment of oil and gas CEOs?

\subsection{Hypotheses}

Before any analysis was carried out to answer the research question outlined in paragraph 2.3, three possible hypotheses - Null Hypothesis, Positive Correlation Hypothesis, and Negative Correlation Hypothesis - were formulated. The hypotheses were chosen so that only one hypothesis can be proven to be true. If any of the three hypotheses is proven to be true, the other two hypotheses must be considered false. This was done in an attempt to include all expected results in a mutually exclusive and collectively exhaustive manner. It also allows for the hypotheses to be concise and provably true or false, even if results needed to be reproduced in later research. 


\subsubsection{Null Hypothesis}

The goal of this research is to determine the relationship between two variables: The price of oil and the sentiment of oil and gas CEOs. It cannot be taken for granted that any meaningful relationship between these two variables exists. This research may produce evidence that rejects the other hypotheses. The null hypothesis is supported if no measurable relationship between the variables can be found. In this sense, the Null Hypothesis can be understood as the complementary result to the possible results that are described by the other hypotheses. There are multiple potential reasons why the evidence of this research might support the Null Hypothesis:

There are possible reasons why a relationship between the two variables may not exist. The production of natural gas is closely tied to the production of oil, as both resources are usually found together. As a common source of energy, they can be substitutes for one another. However, there are many specific uses for oil and gas. Oil for example is used in the production of lubricants, waxes, and asphalts, whereas natural gas has its own specialized uses in the petrochemical industry. Due to the many common uses, oil and gas prices have been found to affect each other. Though, new research suggests, that the relationship between oil price and gas price is largely decoupled since 2006, possibly due to new technology (Batten, Ciner, \& Lucey, 2017). Ever since the decoupling occurred, the crude oil price has mostly been higher relative to the natural gas price per equivalent amount of energy. Similar to how oil prices and gas prices decoupled, there could be a decoupling of oil prices and sentiment. Large oil companies like Shell are active in more than just the oil exploration business. So, if a decrease in oil prices makes the oil exploration business less profitable, CEO sentiment may no longer be coupled to the oil price, but to the performance of other business units. When oil prices decrease, executives might have an incentive to emphasize the performance of their refining, carbon trade, or natural gas business. This could potentially lead to a temporary or permanent decoupling of oil prices and sentiment, which would lead to the null hypothesis being partially or fully true.

There may also be reasons why the null hypothesis cannot be proven false, even if a relationship between the variables exists. One such reason could be that the effect of oil prices on sentiment is small in comparison to other influences. The event or venue of the speech may have a larger influence on the speech, than the price of oil. Additionally, there might be cultural paradigms or professional obligations, which could veil or reduce the oil price's impact on the CEO's sentiment in his or her speech. In those cases, it would be challenging or even impossible to prove the null hypothesis false.

\subsubsection{Positive Correlation Hypothesis}

This hypothesis is supported if evidence suggests that an increase in price of oil correlates to an increase of sentiment, and that a decrease in price of oil correlates to a decrease of sentiment. 
An increase of oil prices generally results in an increase of speech sentiment of oil and gas executives. A decrease of oil prices generally results in a decrease of speech sentiment of oil and gas executives.

\subsubsection{Negative Correlation Hypothesis}

This hypothesis is supported if evidence suggests that an increase in price of oil correlates to a decrease of sentiment, and that a decrease in price of oil correlates to an increase of sentiment.

This Hypothesis may be expected based on findings of a previous study. This study (Apergis, Cooray, \& Ur Rehman, 2018) observed that high oil prices will lead to a lower investor sentiment: "oil prices exert a negative impact on investor sentiment, which is in favor of what was expected. Higher oil prices lead to a stressful macroeconomic environment which contributes to high inflation and strong inflationary expectations, with a monetary policy response that will be conducive to higher interest rates, leading to a decline in investor sentiment." (p. 135) Intuitively, it can be argued that a decline in investor sentiment should lead to a lower sentiment of oil and gas producers, as interests of both groups are largely aligned. Therefore, an increase in oil price should result in a decrease in sentiment of oil and gas producers.

\subsection{Revised Hypotheses}

The initial hypotheses in paragraph 2.4 were later expanded based on insights from data exploration described in 3.2.4. The data exploration indicated that a correlation between oil price and sentiment seems possible. However, the correlation coefficient may not be stationary, but dynamic. This possibility was not considered when the initial three hypotheses were formulated. The initial hypotheses assume the coefficient to be stationary. Therefore, to account for the possibility of a nonstationary coefficient a fourth and fifth hypothesis were added. Hypothesis 2.5.1, if proven to be true, renders the initial hypotheses false.

\subsubsection{Dynamic Correlation Hypothesis}

The amount by which an increase (or decrease) in sentiment correlates to an increase (or decrease) in price of oil is not stationary. This amount is a dependent variable, which may assume positive or negative values.

\subsubsection{Dynamic Coefficient Correlates to Price of Oil Hypothesis}

This hypothesis adds to hypothesis 2.5 .1 by specifying that the amount by which an increase (or decrease) in sentiment correlates to an increase (or decrease) in price of oil negatively correlates to the price of oil. 
This hypothesis is only true if the hypothesis 2.5.1 is true, as it describes a subset of the hypothesis. However, given that hypothesis 2.5.1 is true, does not imply that hypothesis 2.5.2 must also be true. 


\section{Methods}

This study uses a combination of methods in order to test the hypotheses outlined in paragraph 2.4 and produce evidence for answering the research question in paragraph 2.3 .

In paragraph 2.4 it was established that only one of the three hypotheses can be true at all times, and failure to prove Positive Correlation Hypothesis and the Negative Correlation Hypothesis to be true results in evidence for the Null Hypothesis. Therefore, this study tested the Positive Correlation Hypothesis and the Negative Correlation Hypothesis. Given the nature of these hypotheses, it seemed most appropriate and effective to test them using an empirical approach. For the empirical approach, data was needed. This data had to be selected and acquired.

\subsection{Detailed Description}

Based on the hypotheses, two data sets were needed. One dataset had to represent the price of oil and the other dataset had to represent sentiment of oil and gas CEOs. Both data sets had to be a time series so that the observations of one data set could be matched with the observations of the other data set based on the time of the observations.

Several data sources were considered, and it was concluded that the sentiment data would be best obtained as primary data. As a precursor for the desired sentiment data, speech transcripts needed to be obtained. However, before any data could be collected, systematic selection criteria needed to be defined to guarantee representative data and meaningful hypothesis testing. This was achieved using the method of Representative Sampling as specified in paragraph 3.2.1. This method resulted in a selection of speech data that needed to be obtained. The speech data in this selection was obtained using Qualitative Data Acquisition as specified in paragraph 3.2.2. Measurements of sentiment in the collected speech transcripts were obtained using the method of Analysis. Aspect-Based Sentiment Analysis as specified in paragraph 3.2.3. The result of this method was quarterly sentiment data, which was joined as an inner join with the quarterly oil price data to form one dataset. Resulting data of this data join is documented in Table $\mathbf{1 .}$

The newly formed dataset was then explored using the scientific method of MultiDimensional Linked-View Data Exploration as specified in paragraph 3.2.4. As a result of the data exploration, it was suspected that both, positive and negative correlation was present in the sample. Given the learnings from the data exploration, the initial hypotheses needed to be revised. Instead of testing whether the entire sample contains positive or negative correlations, it was necessary to test when the sample contains positive correlations and when it contains negative correlations. To test for 
and measure the suspected correlations, the scientific method of linear regression was used.

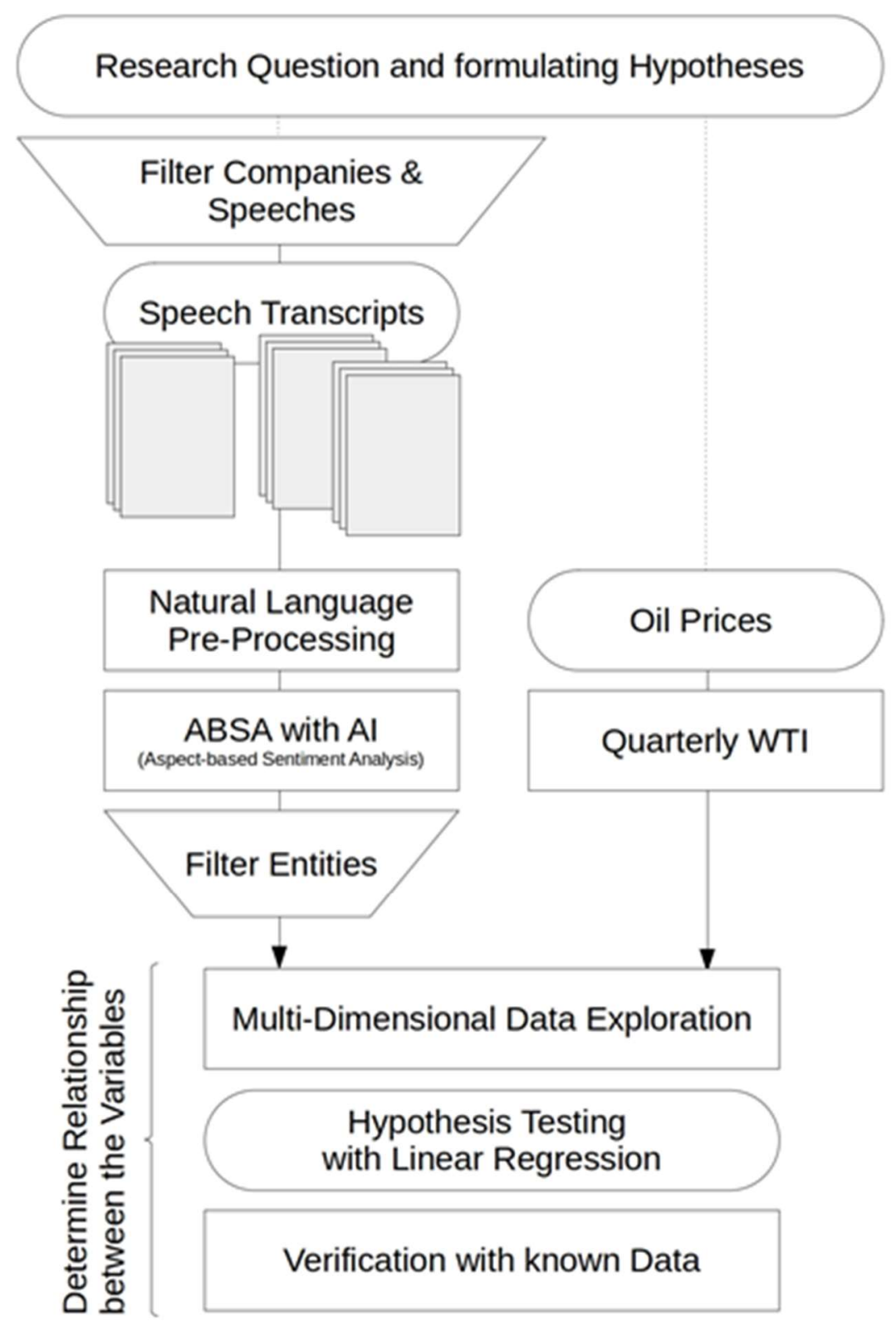

Figure 3 - Overview Methodology

The results of the analysis raised questions about the transition between positive and negative correlation phases. To visually understand the transition between positive and negative correlation, another variation of data exploration was used. This variation was applied to highlight the order of observations during the transition phase. 


\subsection{Scientific Methods used in this Research}

\subsubsection{Representative Sampling}

The speech transcripts, which are selected in this study, must meet select criteria.

- $\quad$ speech held by chief executive officer (CEO)

- was published on the company's website

- speech published in English language

- $\quad$ speech held between 2014 and 2019

Additionally, companies were selected by the following criteria.

- multiple suitable speech transcripts must be available for each year

- company needs to be active in the upstream oil and gas market

Market capitalization in 2019 was used to ensure that only companies of high relevance to the market were selected. Companies were first sorted by market capitalization (descending) and then tested for the above criteria, until a selection of 5 companies was made. The smallest selected company is Gazprom with 88 Billion USD in 2019. To avoid dilution of results with less market relevant data, no companies smaller than Gazprom were selected.

\subsubsection{Qualitative Data Acquisition}

Speeches were manually obtained from each company's website. In the case of Saudi Aramco and BP some of the speeches were previously accessible through the company's website but have later been removed. These removed speeches were retrieved through a website archival service ${ }^{1}$.

The speech transcripts were collected manually to ensure the best data quality. Speech transcripts were then preprocessed automatically to guarantee consistency and homogeneity. Preprocessing consisted of removal or replacement of some special symbols (e.g. ${ }^{\text {тм }},\left(C^{2},{ }^{1}, 0\right.$ ), as well as removal of line breaks and redundant whitespace. After initial collection and processing, the data possessed the necessary properties to conduct Sentiment Analysis. Aspect-Based Sentiment Analysis Speech Sentiment was analyzed algorithmically using a proprietary machine-learning algorithm. Using this method to analyze speech sentiment provided sentiment values for all entities in all sentences of all selected speeches - sentiment for more than 60,000 entities was measured. All entities received a sentiment score. This score ranges from -0.9 (very negative sentiment) to 0.9 (very positive sentiment) in increments of 0.1 with a score of 0.0 being indicative of a neutral sentiment.

\footnotetext{
${ }^{1}$ (web.archive.org)
} 
The dataset was filtered by keywords. Samples needed to contain "oil", or "crude". These keywords were chosen to ensure a favorable tradeoff between sample size and avoiding inclusion of unrelated subsets. To increase resolution and precision of sentiment data, sentiment data was aggregated and averaged on a quarterly basis.

When choosing this method, one of the concerns was that the type of natural language data - transcripts of executives' speeches - might be more neutral than most other natural language data. This study, however, is less concerned with absolute sentiment values, but specifically how these values change over time.

\subsubsection{Aspect-Based Sentiment Analysis}

Speech Sentiment was analyzed algorithmically using a proprietary machine-learning algorithm. Using this method to analyze speech sentiment provided sentiment values for all entities in all sentences of all selected speeches - sentiment for more than 60,000 entities was measured. All entities received a sentiment score. This score ranges from -0.9 (very negative sentiment) to 0.9 (very positive sentiment) in increments of 0.1 with a score of 0.0 being indicative of a neutral sentiment.

The dataset was filtered by keywords. Samples needed to contain "oil", or "crude". These keywords were chosen to ensure a favorable tradeoff between sample size and avoiding inclusion of unrelated subsets. To increase resolution and precision of sentiment data, sentiment data was aggregated and averaged on a quarterly basis.

When choosing this method, one of the concerns was that the type of natural language data - transcripts of executives' speeches - might be more neutral than most other natural language data. This study, however, is less concerned with absolute sentiment values, but specifically how sentiment values change over time.

\subsubsection{Multi-Dimensional Linked-View Data Exploration}

Initially, data was checked for plausibility and quality. Data exploration was then conducted with a linked-view exploration approach. Datapoints in one view (time series line chart) could easily be identified in the other view (scatter plot) and viceversa. The data exploration was done to become familiar with the data before any hypotheses were formally tested in the subsequent steps. During the exploratory data analysis, it became clear that basic assumptions about the data were not correct and that the initial hypotheses in 2.4 needed to be revised in order to have meaning in the context of the data.

\subsubsection{Linear Regression}

The data was tested for positive and negative correlation using linear regression. This means that the statistical model that has been tested is a linear model. If the 
relationship between commodity or security pricing and measured sentiment was a fully linear relationship, any increase or decrease in pricing would always result in a proportional increase or decrease of sentiment. This, however, is unlikely because commodity prices can take any value in the set of rational numbers. A practical example, that oil can be priced below 0 USD, was demonstrated in April 2020 when derivatives of WTI crude oil traded for less than -30 USD per barrel due to lack of available storage. Theoretically, there is no limit for how high or low oil or other commodity prices could rise or fall over time. Measured sentiment score on the other hand cannot take any values below -0.9 or above +0.9 . Therefore, a linear relationship between prices and sentiment can inherently not be expected to sustain arbitrarily high price fluctuations. Eventually, the sentiment score would be predicted to hold values that are outside the set of possible values. It would, therefore, be surprising if the data were fully compatible with a linear model all the time.

However, using a linear model is sufficient for testing the given hypotheses and provides valuable insights into the general relationship between the two variables. A more realistic and reliable model can be built by mapping the values with a function, so that the relationship between both variables can be analyzed with linear regression. Therefore, even arbitrarily high or low values of the independent variable would not break from the model. As a first iteration step towards this goal, the sentiment values were multiplied by a scaling factor $0.5 \times \pi \div 0.9=1.745$ before applying the tangent function to this value. The resulting values were then used as the measure for sentiment because this sentiment measure can theoretically span the entire set of rational numbers, just as the oil price. This minor adjustment already improves the realism of the model and increases the model's reliability at extreme values. More sophisticated adjustments may further improve the model's reliability and fit.

\subsection{Data Science Equipment Used in This Research}

The practical use of some scientific methods as outlined in paragraph 3.2 relies on powerful software algorithms. For best reproduction of this study's results, the following data science software is recommended.

Data in this study was processed entirely with the Konstanz Information Miner (KNIME) Analytics Platform ${ }^{2}$ in version 4.1.2. This software was also used to generate statistical data in Table 2 , Table 3 , and Table 4 , as well as plotting Figure 8, Figure 9, and Figure 10 in this paper. Other state of the art data analysis software is expected to produce similar or even identical results.

This study uses Google Cloud Natural Language API ${ }^{3}$ Version 1 for aspect-based sentiment analysis as detailed in paragraph 0 . Measurement results of this study are

\footnotetext{
2 (www.knime.com)

${ }^{3}$ (cloud.google.com/natural-language)
} 
identically reproducible when using the same sentiment algorithm. Measurements may vary when using other sentiment algorithms depending on factors such as measurement precision and measurement accuracy.

Multi-dimensional linked-view data exploration, as specified in paragraph 3.2.4, was conducted with Glue ${ }^{4}$ to achieve a deeper understanding of the relationships between independent and dependent variables over time. The visualizations in Figure 7 have been generated using Glue.

4 (www.glueviz.org) 


\section{Results}

The list of speeches used in this study is available in the attachment.

This table is the aggregated and joined data, which serves as the main dataset in this study.

\begin{tabular}{|r|r|r|}
\hline Quarter & Oil Price (WTI) in USD & Entity Sentiment Score \\
\hline 2014 Q1 & 98.8 & 0.065 \\
\hline 2014 Q2 & 103.1 & 0.055 \\
\hline 2014 Q3 & 97.6 & 0.062 \\
\hline 2014 Q4 & 73.1 & 0.088 \\
\hline 2015 Q1 & 48.7 & 0.191 \\
\hline 2015 Q2 & 57.8 & 0.333 \\
\hline 2015 Q3 & 46.5 & 0.055 \\
\hline 2015 Q4 & 42.0 & 0.089 \\
\hline 2016 Q1 & 33.3 & 0.081 \\
\hline 2016 Q2 & 45.5 & 0.075 \\
\hline 2016 Q3 & 44.9 & 0.062 \\
\hline 2016 Q4 & 49.2 & 0.098 \\
\hline 2017 Q1 & 51.8 & 0.095 \\
\hline 2017 Q2 & 48.3 & 0.097 \\
\hline 2017 Q3 & 48.1 & 0.088 \\
\hline 2017 Q4 & 55.4 & 0.108 \\
\hline 2018 Q1 & 62.9 & 0.120 \\
\hline 2018 Q2 & 67.9 & 0.135 \\
\hline 2018 Q3 & 69.7 & 0.066 \\
\hline 2018 Q4 & 58.7 & 0.076 \\
\hline 2019 Q1 & 54.8 & 0.194 \\
\hline 2019 Q2 & 59.8 & 0.121 \\
\hline 2019 Q3 & 56.4 & 0.082 \\
\hline 2019 Q4 & 57.0 & 0.098 \\
\hline
\end{tabular}

Table 1 - Aggregated Values of both Variables. Values have been rounded. 


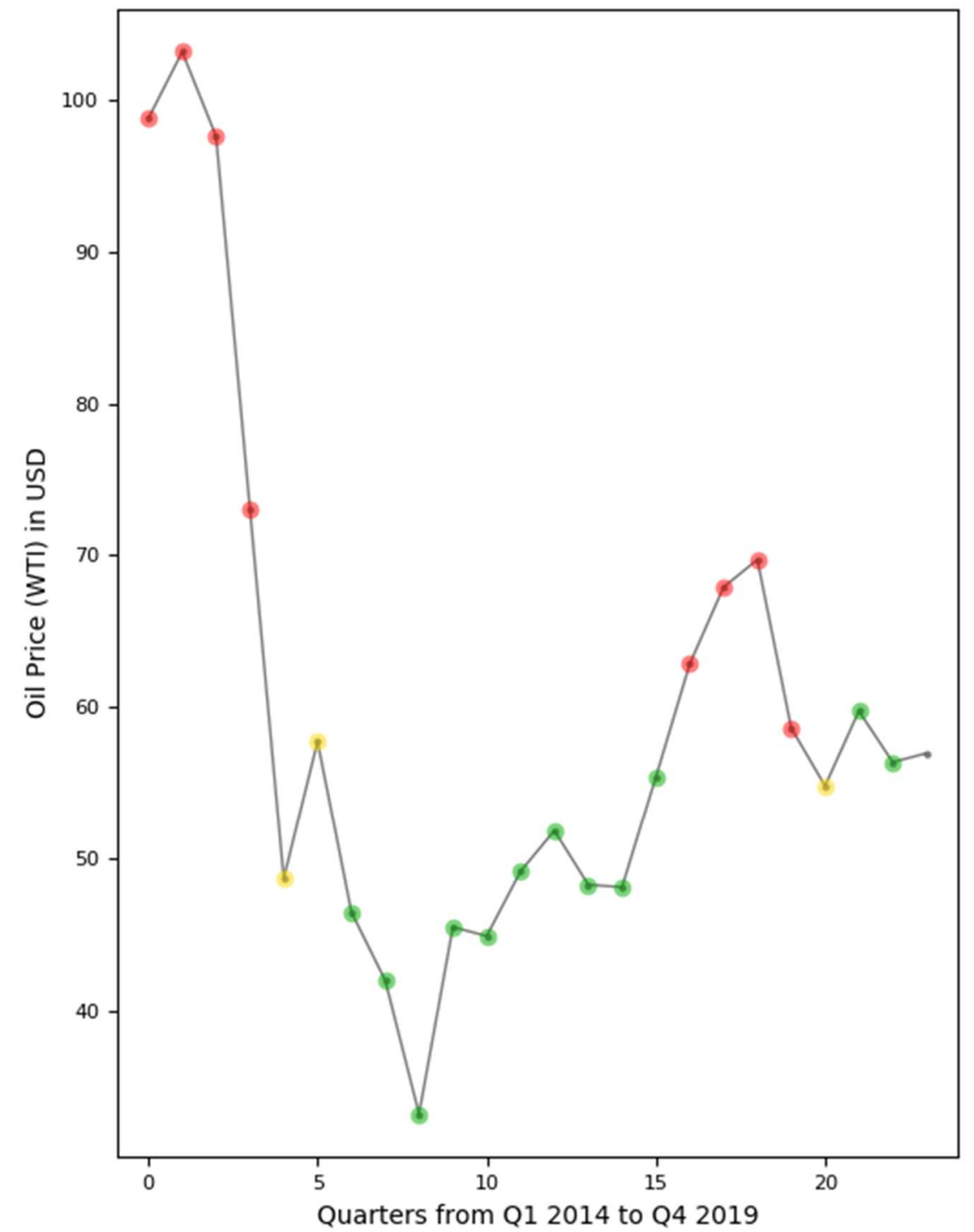

Figure 4 - Multi-Dimensional Data Exploration - Price over Time; Colors to aid perception of data relation across multiple dimensions. 


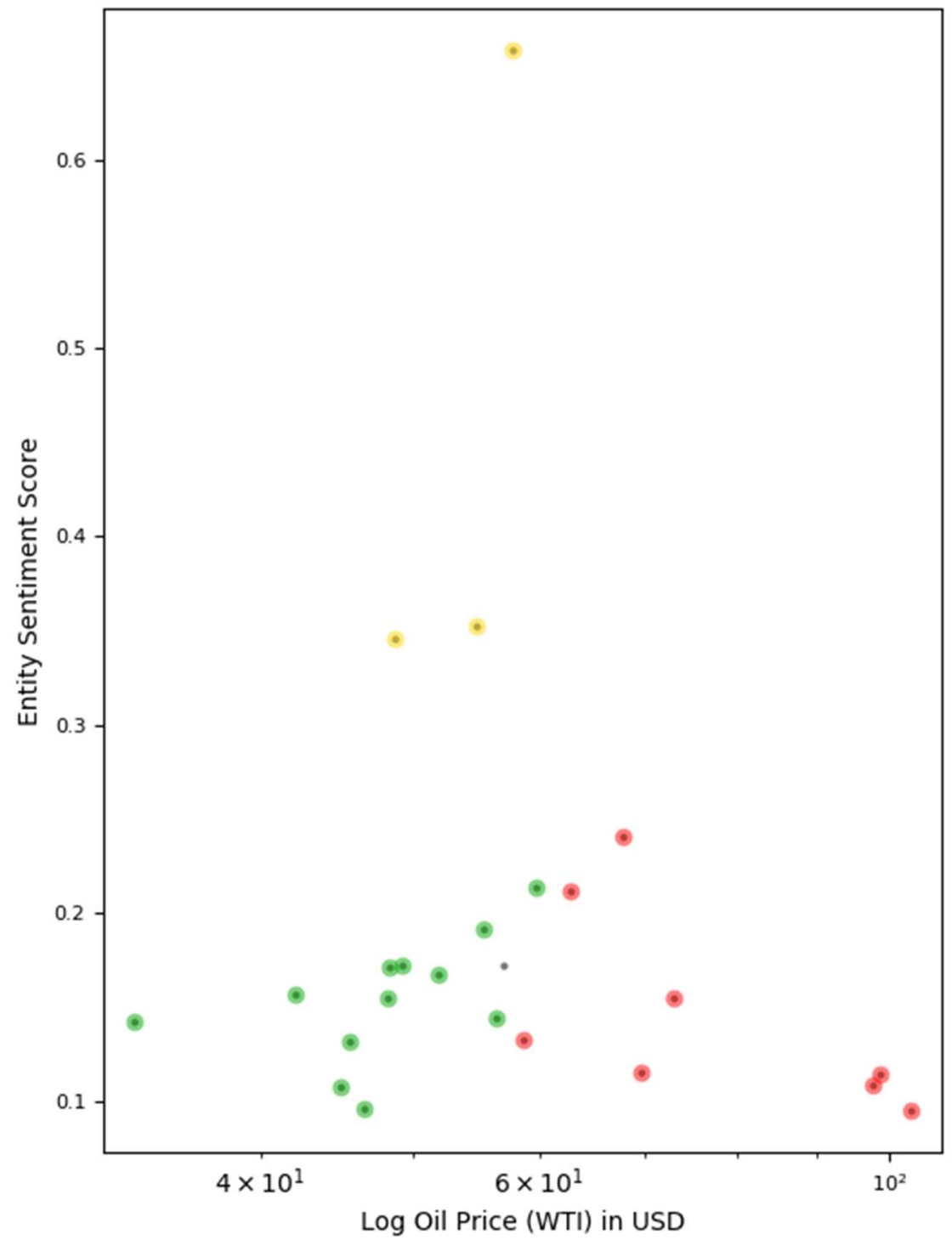

Figure 5 - Multi-Dimensional Data Exploration - Oil Sentiment Score by Oil Price; colors to aid perception of data relation across multiple dimensions. 


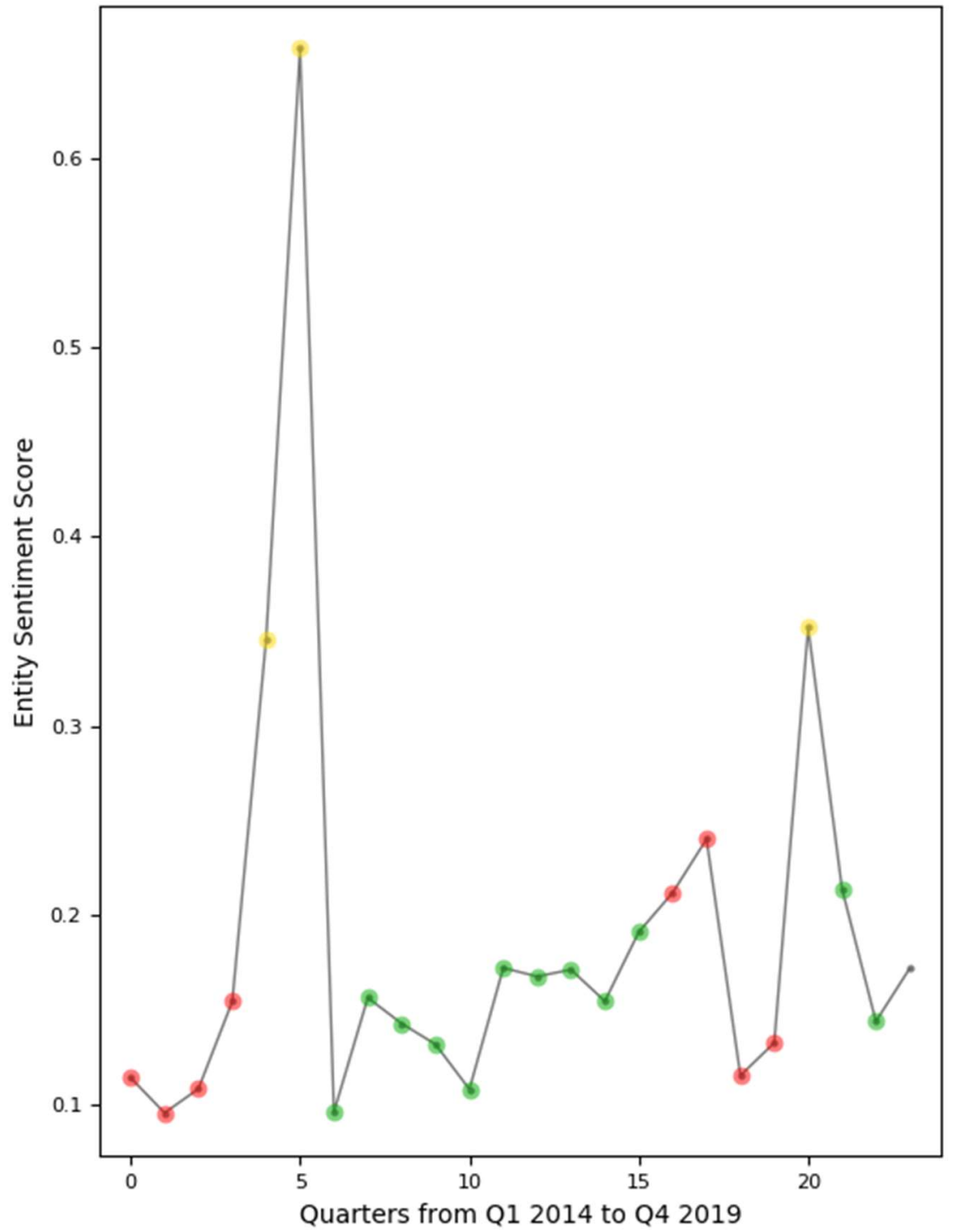

Figure 6 - Multi-Dimensional Data Exploration - Sentiment over Time; Colors to aid perception of data relation across multiple dimensions. 


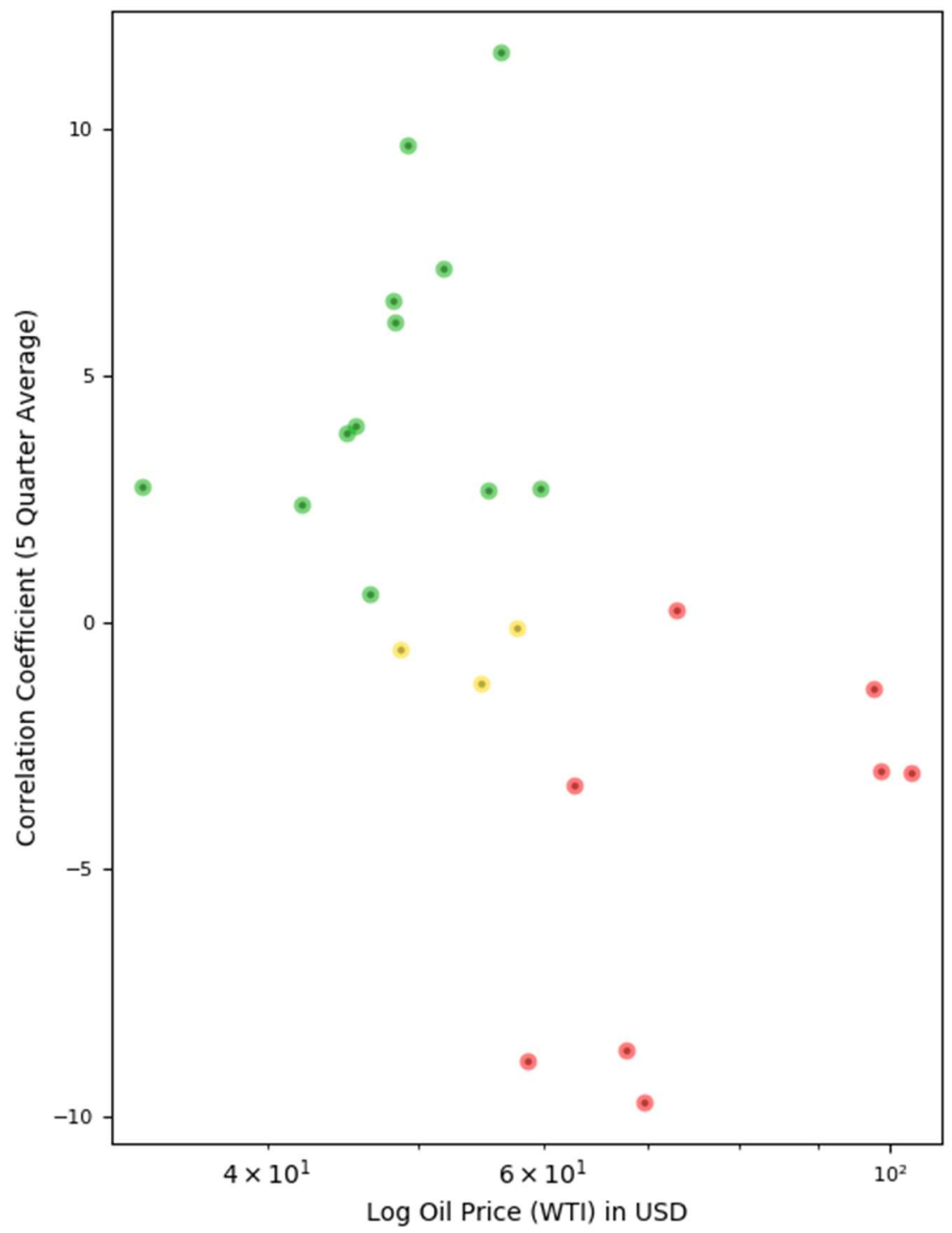

Figure 7 - Multi-Dimensional Data Exploration Sentiment - Correlation Coefficient (= Sentiment Change [\%] per Dollar Change [\%]) by Oil Price; Colors to aid perception of data relation across multiple dimensions. 


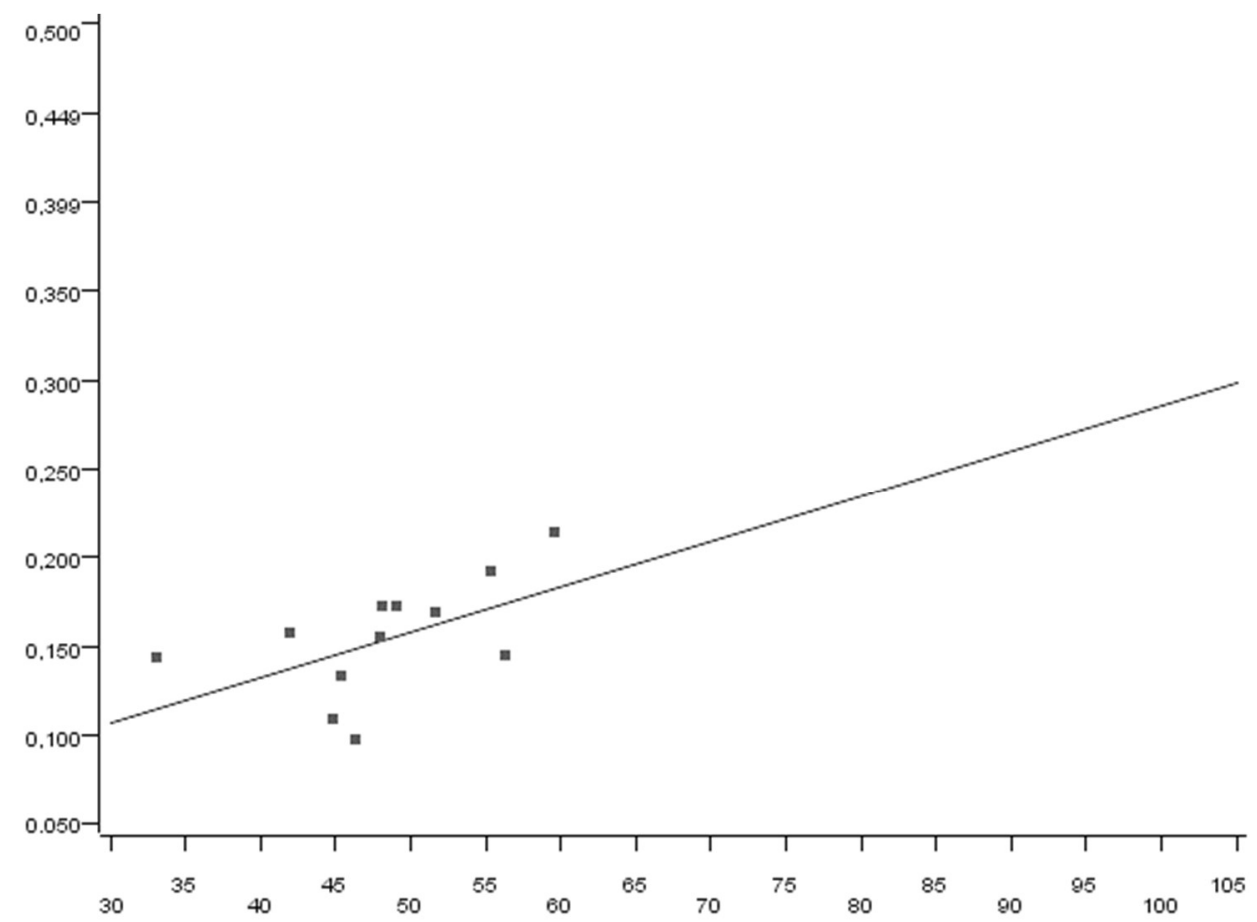

Figure 8 - Linear Regression Plot of Sentiment by Price; Green Subset from Figure 7

Variable Coeff. Std. Err. t-value $P>|t|$

POILWTIUSDQ 0,0026 0,0012 2,0778 0,0644

Intercept $\quad 0,03060,0601 \quad 0,508 \quad 0,6225$

Table 2 - Linear Regression Statistics of Sentiment by Price; Green Subset from Figure 7 


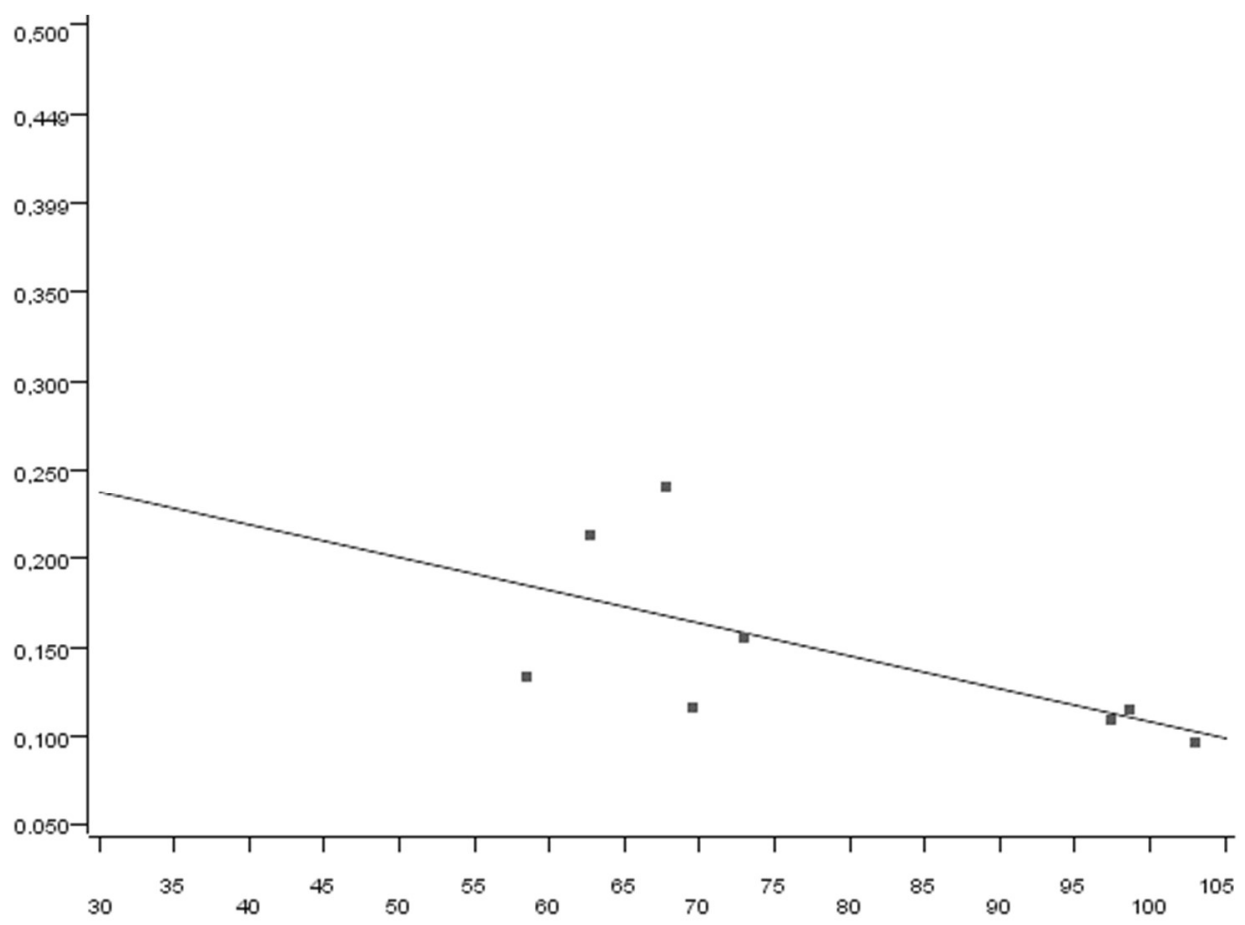

Figure 9 - Linear Regression Plot of Sentiment by Price; Red Subset from Figure 7

Variable Coeff. Std. Err. t-value $P>|t|$

POILWTIUSDQ -0,0018 0,0009 -1,9871 0,0941

Intercept $\quad 0,29250,0749 \quad 3,90250,008$

Table 3 - Linear Regression Statistics of Sentiment by Price; Red Subset from Figure 7 


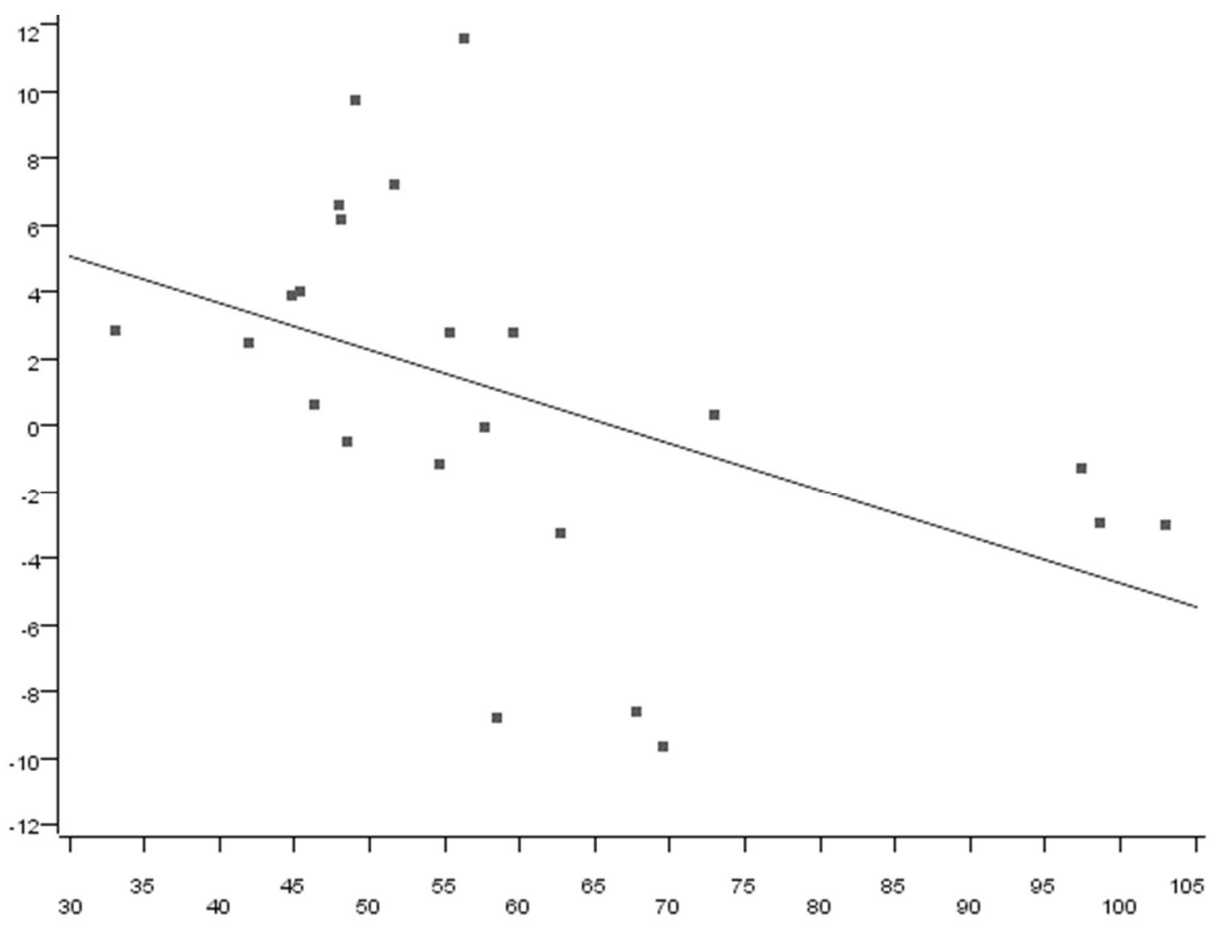

Figure 10 - Linear Regression Plot of Sentiment Change [\%] per Dollar Change [\%] by Price

Variable Coeff. Std. Err. $t$-value $P>|t|$

POILWTIUSDQ -0.1406 $0.0584 \quad-2.406 \quad 0.0254$

$\begin{array}{lllll}\text { Intercept } \quad 9.3035 & 3.6458 & 2.5518 & 0.0186\end{array}$

Table 4 - Linear Regression Statistics of Sentiment Change [\%] per Dollar Change [\%] by Price 


\section{Discussion}

\section{What does this data mean with regards to the revised hypotheses?}

The initial hypotheses in paragraph 2.4 were revised based on insights from exploratory data exploration described in 3.2.4. Data exploration indicated that correlation between oil price and sentiment is likely not static. Based on this insight the hypotheses were revised, as described in section 2.5.

The revised hypotheses 2.5.1 and 2.5.2 were tested. Evidence for hypothesis 2.5.1 to be true was found in Table 2 and Table 3, where subsets of consecutive measurements showed positive (see Figure 8) or negative correlations (see Figure 9), depending on oil price. The higher price subset correlates negatively to oil price and the lower price subset correlates negatively, with reasonably high significance, given the small size of the subsets. Validity of hypothesis 2.5 .2 was first tested with linear regression. The statistical test results in Table 4 provide further significant evidence for hypotheses 2.5 .1 and 2.5.2 to be true. A final quantitative, and more practical test for these hypotheses to be true, was performed. In this test the statistical model used to prove the hypotheses predicted a known economic value. The statistical model accurately predicted the known value, which further adds to the evidence for both hypotheses to be true.

What does this data mean regarding the initial hypotheses?

Given that the revised hypotheses have been tested true, the initial hypotheses cannot be fully true as defined in paragraph 2.5. However, all three initial hypotheses can be viewed as temporarily true, as there are consecutive Quarters where each of the initial hypotheses can be tested as true. For data at (or near) the threshold price, the Null Hypothesis is true. For data below the threshold price, the Positive Correlation Hypothesis is true. Lastly, for data above the threshold price, the Negative Correlation Hypothesis is true.

What about the threshold price?

The threshold price has been observed to be the price at which sentiment does not have a measurable linear dependence on the oil price (as hypothesized in the Null Hypothesis). The modeled regression line $y=-0.1406 x+9.3035$ (values as in Table 4) predicts no change in sentiment $(y=0)$ at an oil price of $x=66.20$ USD. The function has been visualized in Figure 10. If prices are assumed to be distributed log normally, the resulting model predicts $\mathrm{y}=0$ at $\mathrm{x}=63.10$ USD.

This price was determined using a locally calculated and averaged coefficient that predicts how much the sentiment increases or decreases for each dollar that the oil price increases or decreases. 
Therefore, using the linear regression model, the coefficient was predicted to be 0 at an oil price of 63 USD per barrel of WTI crude oil, which is the threshold price in the observed period. The farther above (or below) the current oil price is from the threshold price; the lower (or higher) this coefficient is predicted to be. This can also be observed in Figure 7. The data points clusters have been colored to allow easier recognition across Figures. In Figure 4, which simply shows oil price over time, it becomes apparent that red data points, indicating a negative correlation, appear chronologically consecutive when price is high. Green data points, indicating positive correlation, generally appear chronologically consecutive when price is low. Yellow data points, indicating little correlation, appear in the transition between the positive and negative correlation. Yellow data points are also associated with a very high sentiment score as can be seen in Figure 6, while the red and green marked data points are associated with lower sentiment. In Figure 5, which shows sentiment by price, it becomes clear that the sentiment itself is generally highest at moderate price levels and decreases towards more extreme (higher and lower) oil prices.

\section{How does this threshold price tie in with the existing theory?}

Since a positive correlation between sentiment and oil price suggests that oil producers are in favor of a higher oil price and negative correlation suggests that oil producers are in favor of a lower oil price. The test results suggest that there is an oil price, the threshold price, which the oil producers favor the most. Prices higher or lower than the threshold price is perceived as disadvantageous. This can be expected when considering the contemporary context of the industry. In the introduction of this paper, some of the current and future challenges of the oil and gas producers were highlighted. Figure 1 indicates at which prices oil producers can become profitable and enter or leave the market. Above a certain price traditional oil producer lose their market shares to new competitors. Additionally, governments whose economies are negatively impacted by a high oil price may introduce policies to regulate the oil market. Both generally are not in the interest of established oil producers. On the other hand, a lower market price leads to lower profitability for traditional oil extraction. This means that there is an optimal price for traditional producers. Analysts have estimated this optimal price to be between 60 and 70 USD for 2018. (Petroff, 2018) This is in line with the calculation of this model, which predicts this price to be 63 USD.

Given the background of an ideal oil price it becomes clear that this price ideal is subject to change over time. As alternatives to traditional oil extraction and oil substitutes become more mature, they are likely to be profitable at lower costs. This means, that the inflation adjusted ideal price can be expected to decrease as alternatives to traditional oil extraction become cheaper. In contrast, factors such as high inflation or policies against alternatives to traditional oil extraction could cause the ideal oil price to increase. These are examples to show that the ideal price of oil cannot be considered stationary. The threshold price in the model is considered to behave analogous to the ideal oil price. Therefore, the threshold price in the model is 
not expected to be stationary. As this model relies on multiple data points in a timeseries to calculate the threshold price, there is a tradeoff where a longer observation time may reduce data noise but could introduce "blur" from a moving threshold price. This, of course, would not be of concern if this price could be considered stationary.

\section{Do the ABSA results contain information that could not be retrieved with other methods?}

The research question and hypotheses were chosen to demonstrate the abilities of a method based on ABSA in economic research. Therefore, ABSA was used in this research to measure the sentiment of producers in a submarket regarding one of their products - a use case that would, for the existing methods discussed in 1.2, proof very challenging, and has not been demonstrated yet. To validate and demonstrate that the measurements obtained with this method are meaningful and accurate, the sentiment values were used to calculate the ideal price of oil. The ideal price of oil has been determined by different market analysts using other methods. Thus, the existing results served as a ground truth. These known values and the results calculated using only sentiment measurements have shown to support each other. Subsequently, the ability to calculate the ideal price of oil is not novel. Although, the ability to obtain accurate sentiment measurements from natural language of producers in a specific market only regarding a specific aspect is a differentiator of the demonstrated method. 


\section{Conclusion}

The research question focuses on the relationship between price of oil and sentiment of leaders in the upstream oil industry. It was found that the sentiment correlates positively and negatively to the price of oil depending on the price level. If the oil price exceeds a certain value, the sentiment correlates negatively. If the oil price is below that same value, the sentiment correlates positively with the oil price. In the 24 quarters sample, this threshold dollar value was determined to average 63 USD per barrel of WTI.

The method used in this study is based on sentiment analysis. The method differs from other methods, such as surveys and interviews, and is possibly superior in some respects. When it comes to cost and scalability this method compares favorably to traditional alternatives. In contrast to surveys and interviews, the measured data reflect subtle unconscious language changes, so that the "interviewed" persons can rarely consciously influence the results.

It may also be used to "interview" people who, for various reasons, are not available for a traditional interview. The prerequisite is that sufficient language material is available (e.g. transcripts, correspondence, tweets, or posts). Historical figures may also be "asked" about their opinions on specific topics. Among other fields of study, this aspect could prove valuable for economic history research.

More relevant than the historical sentiment is the possible use of this method to analyze current natural language data, such as comments from business journalists and market experts. This method can be implemented in real time, which would certainly make it more interesting for analysts and investors. A real-time implementation of this method could help investors to respond quickly and appropriately to sentiment swings associated with events in markets around the world. Researchers found that the pricing of more speculative, hard to arbitrage stocks is driven by sentiment (Jiang, et al., 2016). This was also concluded in the findings of an earlier study (Baker \& Wurgler, Investor sentiment in the stock market., 2007). In those cases, this method may be used to complement traditional pricing models. Both the economic concepts of homo economicus and efficient-market hypothesis hinge on the idea that all publicly available information is taken into account in a rational decision-making process of an individual (homo economicus) and is already taken into account in market pricing (efficient-market hypothesis). An implementation based on this method could potentially contribute to more efficient markets, as this method allows for price-sensitive sentiment information to be objectively processed in real-time - a task, which an individual human cannot manually fulfill.

Such an implementation could take the form of an index. Investors could use this index to decide whether to take short or long positions, or to hold oil and other 
commodities. However, more stringent back tests with specialized simulations would be required to confirm the practical use of this method in such an application.

The evidence produced by this research rejects a linear relationship between price and CEO sentiment. However, this research produced evidence that supports a nonlinear relationship between price and CEO sentiment, which in turn rejects the possibility that there is no relationship between price and CEO sentiment. Given this conclusion, one might wonder about the exact non-linear relationship between price and CEO sentiment. It was demonstrated that higher prices lead to a more negative relationship between prices and CEO sentiment, while lower prices lead to a more positive relationship between prices and CEO sentiment. It was also shown at which price the relationship turns from a positive relationship to a negative relationship in the given sample. These findings suffice to fully answer the given research question.

Furthermore, given the research conclusion and collected data, it seems possible to build a model that predicts oil company CEO sentiment at a given crude oil price and ideal crude oil price for those companies. Naturally, such a model would also predict the ideal oil price, as well as the oil price, when the other two variables are known, and the equation is rearranged.

The exact mathematical function of the non-linear relationship is, however, difficult to determine with certainty from the empirical data. Such a model, if based for example on a quadratic function, might perform well in familiar value ranges and predict poorly outside of the known range if the true non-linear function is not actually a quadratic function. There are several plausible candidates for the underlying nonlinear function, which leaves room for future research and experiments. However, knowledge of the exact nature of the function should not be relevant for most practical applications.

Unlike previous research this study did not focus on predicting future prices. The focus of this study was to understand how Leadership Sentiment and changes in pricing are related. This does not mean that Leadership Sentiment only depends on pricing. Contrary, the Leadership Sentiment could be affected by a broad range of factors. To filter for price related sentiment and avoid cross interferences this study used Aspect-Based Sentiment Analysis. However, the same method could be useful to determine or further segment other factors that influence leadership sentiment. 


\section{Limitations}

Little available research on the specific subject

The specific subject of this study is rather new and has not been exhaustively studied by other researchers. Therefore, the data in this study has been interpreted as is without relying on other studies as a frame of reference. Technology used in this study is currently evolving at a rapid pace. Higher quality state-of-the-art technology will produce more accurate and more precise results which enable more effective validation of findings and could lead to less interpretation variance.

\section{Methodology \& Technology Risk}

The design of this study relied on new technology and methods to overcome limitations of traditional approaches. The extend to which the theoretical advantages of the chosen methods benefited this study practically was not demonstrated. This study's methodology was designed around the given research question. However, using new technology does not only come with advantages, but also with additional risks compared to proven-in-use technology.

Data was taken from speeches that were held in a specific timeframe. The method for data collection relies on manual collection and was chosen to ensure data quality but was limited with regards to data quantity. It would have been beneficial if there was more data available for validation purposes. The derived model could have been tested with the data that has not been used for creating the model. Such validation would produce stronger evidence and could be performed in the future when more speech data becomes available. The use of automated data collection could improve available data quantity as well. 


\section{References}

Amano, R. A., \& Van Norden, S. (1998). Oil prices and the rise and fall of the US real exchange rate. Journal of international Money and finance 17, no. 2, 299 316.

Apergis, N., Cooray, A., \& Ur Rehman, M. (2018). Do Energy Prices Affect U.S. Investor Sentiment? Journal of Behavioral Finance vol. 19, pp. 125 - 140.

Aquilera, R. F. (2014). Production costs of global conventional and unconventional petroleum. Energy Policy 64, 134 - 140.

Baker, M., \& Wurgler, J. (2007). Investor sentiment in the stock market. Journal of economic perspectives 21, no. 2, pp. 129 - 152.

Baker, M., Wurgler, J., \& Yuan, Y. (2012). Global, local, and contagious investor sentiment. Journal of Financial Economics 104, 272 - 287.

Bannier, C., Pauls, T., \& Walter, A. (2017). CEO-speeches and stock returns. CFS Working Paper Series 583.

Batten, J. A., Ciner, C., \& Lucey, B. M. (2017). The dynamic linkages between crude oil and natural gas markets. Energy Economics 62, 155 - 170.

Brown, G., Cliff, M., Cooper, M., Daniel, K., Kadlec, G., Reed, A., . . Womack, K. (2005). Investor Sentiment and Asset Valuation. Journal of Business, 405 440.

Chen, S.-T., Kuo, H.-I., \& Chen, C.-C. (2010). Modeling the relationship between the oil price and global food prices. Applied Energy 87, no. 8, pp. 2517 - 2525.

CNBC. (2017, July 27). Oil demand could peak in about 10 years, says Shell CEO, sooner than others forecast. Retrieved from https://www.cnbc.com/2017/07/27/oil-will-not-go-out-of-fashionovernight-says-shell-ceo.html

Cunado, J., Gupta, R., Marco Lau, C., \& Sheng, X. (2020). Time-Varying Impact of Geopolitical Risks on Oil Prices. Defence and Peace Economics, 692-706.

Daryl, K., \& Goranova, M. (2018, October). Do Investors See Value in Ethically Sound CEO Apologies? Investigating Stock Market Reaction to CEO Apologies. Journal of Business Ethics, pp. 311 - 322.

Du, D., Gunderson, R. J., \& Zhao, X. (2016). Investor Sentiment and Oil Prices. Journal of Asset Management 17, no. 2, pp. 73 - 88.

Fantazzini, D. (2016). The oil price crash in 2014/15: Was there a (negative) financial bubble? Energy Policy 96, pp. 383 - 396.

Fortune Media IP Limited. (2018, January 24). Inside Oil Giant Shell's Race to Remake Itself For a Low-Price World. Retrieved from http://fortune.com/2018/01/24/royal-dutch-shell-lower-oil-prices/

Gohin, A., \& Chantret, F. (2010). The long-run impact of energy prices on world agricultural markets: The role of macro-economic linkages. Energy Policy 38, no. 1, pp. 333 - 339.

Golub, S. S. (1983). Oil prices and exchange rates. The Economic Journal 93, no. 371, $576-593$. 
Hotelling, H. (1931). The Economics of Exhaustible Resources. Journal of Political Economy Vol. 39, No. 2, 137 - 175.

Huang, D., Jiang, F., Tu, J., \& Zhou, G. (2015). Investor Sentiment Aligned: A Powerful Predictor of Stock Returns. Review of Financial Studies, 791 - 837.

Jiang, F., Lee, J., Martin, X., Zhou, G., Doukas, J., Li, W., . . . Zhou, H. (2016). Manager Sentiment and Stock Returns.

Kabundi, A., \& Ohnsorge, F. (2020). Implications of Cheap Oil for Emerging Markets. Policy Research Working Paper.

Kaerney, L. (2020, 04 21). What is a negative crude future and does it mean anything for consumers? Retrieved from www.reuters.com: https://www.reuters.com/article/us-global-oil-crash-explainer/explainerwhat-is-a-negative-crude-future-and-does-it-mean-anything-forconsumers-idUSKBN22301M

Lutz, K., \& Zhou, X. (2019). Oil prices, exchange rates and interest rates. CESifo Working Paper No. 7484, 1 - 53.

Petroff, A. (2018, 05 18). What is the perfect price for oil? Retrieved from CNNMoney: https://money.cnn.com/2018/05/18/investing/oil-pricesbest-price/index.html

Qadan, M., \& Nama, H. (2018). Investor sentiment and the price of oil. Energy Economics 69, pp. 42 - 58.

Ronen, D. (2011). The effect of oil price on containership speed and fleet size. Journal of the Operational Research Society 62, no. 1, 211 - 216.

Saudi Aramco. (2015, 02 16). Offshore Northern Seas Conference 2014. Retrieved from

https://web.archive.org/web/20150216205539/http://www.saudiaramco .com/en/home/news-media/speeches/Offshore-Northern-SeasConference.html

Shell. (2015, 10 06). More Oil, Less Money. Retrieved from https://www.shell.com/media/speeches-and-articles/2015/more-oil-lessmoney.html

Sy, T., Côté, S., \& Saavedra, R. (2005). The Contagious Leader: Impact of the Leader's Mood on the Mood ofGroup Members, Group Affective Tone, and Group Processes. Journal of Applied Psychology, 295 - 305.

Van de Graaf, T. (2018). Battling for a Shrinking Market: Oil Producers, the Renewables Revolution, and the Risk of Stranded Assets. In D. Scholten, The Geopolitics of Renewables. Lecture Notes in Energy, vol 61 (pp. 97 - 121). Springer, Cham. 


\section{Attachment}

\section{List of analyzed speeches}

\begin{tabular}{|c|c|c|c|c|}
\hline $\begin{array}{l}\text { Speech } \\
\text { Date }\end{array}$ & Speaker & Company & $\begin{array}{l}\text { Retrival } \\
\text { Date }\end{array}$ & Source Url \\
\hline 15.01.2014 & Bob Dudley & BP & 07.04 .2020 & http://web.archive.org/web/20140603175831/http://www.bp.com/en/global/corporate/press/speeches/energy-outlook-2035.html \\
\hline $\begin{array}{l}11.03 .2014 \\
10.04 .2014\end{array}$ & $\begin{array}{l}\text { Rex W. Tillerson } \\
\text { Bob Dudley }\end{array}$ & $\begin{array}{l}\text { Exxon Mobil } \\
\text { BP }\end{array}$ & $\begin{array}{l}05.10 .2019 \\
07.04 .2020\end{array}$ & 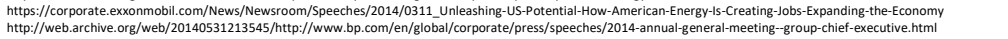 \\
\hline 11.04.2014 & Khalid A. Al-Falih & Saudi & 28.01.2019 & https://web.archive.org/web/20150502032023/http://saudiaramco.com/en/home/news-media/speeches/remarks-at-the-15th-international-oil-summit.html \\
\hline 01.05 .2014 & Rex W. Tillerson & Exxon Mobil & 05.10 .2019 & https://corporate.exxonmobili.com/News/Newsroom/speeches/2014/0501_North-American-Energy-Creating-Opporttunity-and-Transforming-the-World \\
\hline 18.05.2014 & Khalid A. Al-Falih & $\begin{array}{l}\text { Saudi } \\
\text { Aramco }\end{array}$ & 28.01.2019 & https://web.archive.org/web/20150503213157/http://saudiaramco.com/en/home/news-media/speeches/executive-plenary-session-at-middle-east-petrotech-2014.html \\
\hline 20.05.2014 & Ben van Beurden & Shell & 28.01.2019 & https://www.shell.com/media/speeches-and-articles/2014/the-2014-annual-general-meeting-of-royal-dutch-shell-plc.html \\
\hline 29.05 .2014 & $\begin{array}{l}\text { Alexey Muler } \\
\text { Alexey Miller }\end{array}$ & $\begin{array}{l}\text { Gapprom } \\
\text { Gazprom }\end{array}$ & 5.10 .2019 & 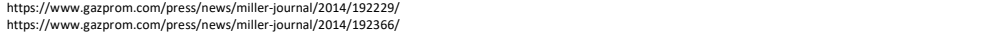 \\
\hline 16.06 .2014 & Rex W. Tillerson & Exxon Mobil & .10 .2019 & 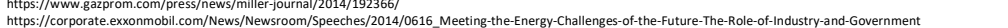 \\
\hline 16.06 .2014 & b Dudley & & 0.01 .2020 & tp://web.archive. org/web/2015031212100018/http:///www.bp.com/en/global/corporate/press/speeches//b-statistical-review-o \\
\hline 17.06.2014 & b Dudley & BP & 30.01.2020 & ttp://web.archive.org/web/20150312102417//http://www.bp.com//en/global/corporate/press/speeches/world-petroleum-cong \\
\hline & & Gazprom & 05.10 .2019 & https://www.gazprom.com/press/news/miller-journal/2014/194608/ \\
\hline 02.07.2014 & Ben van Beurden & & 28.01.2019 & https://www.shell.com/media/speeches-and-articles/2014//a-century-of-ideas.html \\
\hline 25.08.2014 & Khalid A. Al-Falih & $\begin{array}{l}\text { Saudi } \\
\text { Aramco }\end{array}$ & 28.01.2019 & https://web.archive.org/web/20150216205539/http://www.saudiaramco.com/en/home/news-media/speeches/offshore-Northern-Seas-Conference.html \\
\hline 02.09.2014 & Ben van Beurden & Shell & 28.01.2019 & https://www.shell.com/media/speeches-and-articles/2014/working-together-to-build-a-lower-carbon-higher-energy-future.html \\
\hline 19.09.2014 & Khalid A. Al-Falih & $\begin{array}{l}\text { Saudi } \\
\text { Aramco }\end{array}$ & 28.01.2019 & https://web.archive.org/web/20150509010718//ttp://saudiaramco.com/en/home/news-media/speeches/inauguration-of-aramco-research-center-houston.html \\
\hline 19.09.2014 & Alexey Miller & Gazprom & 05.10.2019 & https://www.gazprom.com/press/news/miller-journal/2014/201716/ \\
\hline 23.09.2014 & Khalid A. Al-Falih & $\begin{array}{l}\text { Saudi } \\
\text { Aramco }\end{array}$ & 28.01.2019 & https://web.archive.org/web/20150504143951/http://saudiaramco.com/en/home/news-media/speeches/petroleum-and-industry-session.html \\
\hline 02.10 .2014 & Rex W. Tillerson & Exxon Mobil & $\begin{array}{l}05.10 .2019 \\
0.5102019\end{array}$ & 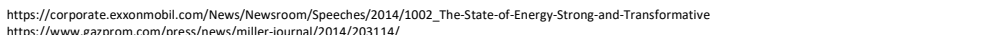 \\
\hline & & $\begin{array}{l}\text { Gazprom } \\
\text { BP }\end{array}$ & $\begin{array}{l}05.10 .2019 \\
30.012020\end{array}$ & https://www.gazprom.com/press/news/miller-journal/2014/203114/ \\
\hline 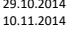 & 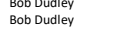 & $\begin{array}{l}B P \\
B P\end{array}$ & $\begin{array}{l}30.01 .2020 \\
30.2020\end{array}$ & 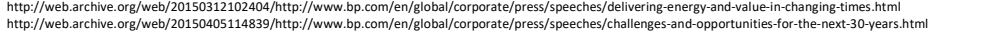 \\
\hline 24.11.2014 & Khalid A. Al-Falih & $\begin{array}{l}\text { Saudi } \\
\text { Aramco }\end{array}$ & 28.01.2019 & $\begin{array}{l}\text { https://web.archive.org/web/20150927180752/http://www.saudiarammco.com/en/home/news-media/speeches/keynote-at-9th-annual-gulf-petrochemicals-chemicals-asso } \\
\text { tio.html }\end{array}$ \\
\hline 03.12.2014 & Khalid A. Al-Falih & $\begin{array}{l}\text { Saudi } \\
\text { Aramco }\end{array}$ & 28.01.2019 & https://web.archive.org/web/20150924182616/http://www.saudiaramco.com/en/home/news-media/speeches/Technovia.html \\
\hline 29.12.2014 & Alexey Miller & Gazprom & 05.10 .2019 & https://www.gazprom.com/press/news/miller-journal/2014/211660/ \\
\hline 12.02 .2015 & Ben van Beurden & Shell & 28.01.2019 & https://www.shell.com/media/speeches-and-articles/2015/less-aloof-more-assertive.html \\
\hline $\begin{array}{l}17.02 .2015 \\
02.032015\end{array}$ & $\begin{array}{l}\text { Boo Dudley } \\
\text { Bob Dudey }\end{array}$ & BP & $\begin{array}{l}30.01 .2020 \\
06.102019\end{array}$ & httpp://web.archive.org/web/20150308092258/http;//www.bp.com/en//lobal/corporate/press//speeches/bp-energy-outlook-2035.html \\
\hline 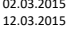 & $\begin{array}{l}\text { Bob Dudley } \\
\text { Rex W. Tillerson }\end{array}$ & Exxon Mobil & 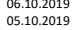 & 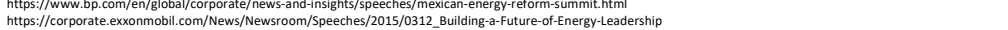 \\
\hline 22.03.2015 & Khalid A. Al-Falih & $\begin{array}{l}\text { Saudi } \\
\text { Aramco }\end{array}$ & 28.01.2019 & https://web.archive.org/web/20150919225530/http://www.saudiaramco.com/en/home/news-media/speeches/CDF2015.html \\
\hline 09.04.2015 & Darren W. & Exxon Mobil & 05.10.2019 & https://corporate.exxonmobili.com/News/Newsroom/Speeches/2015/0409_Building-a-Culture-of-Safety \\
\hline 13.04.2015 & Alexey Miller & Gazprom & 05.10.2019 & https://www.gazprom.com/press/news/miller-journal/2015/223751/ \\
\hline 21.04.2015 & Rex W. Tillerson & Exxon Mobil & 05.10 .2019 & https://corporate.exxonmobili.com/News/Newsroom/speeches/2015/0421_Building-Energy-Policies-Equal-to-the-Technological-Moment \\
\hline 27.04.2015 & Khalid A. Al-Falih & $\begin{array}{l}\text { Saudi } \\
\text { Aramco }\end{array}$ & 28.01.2019 & https://web.archive.org/web/20151017190606/http://www.saudiarammo.com/en/home/news-media/speeches/GlobarMethane.html \\
\hline 02.06.2015 & Ben van Beurden & & 28.01.2019 & https://www.shell.com/media/speeches-and-articles/2015/growing-gas-together.html \\
\hline 02.06.2015 & w. Tillerson & Exxon Mc & 05.10 .2019 & https://corporate.exxonmobili.com/News/Newsro \\
\hline $\begin{array}{l}03.06 .2015 \\
04.06 .2015\end{array}$ & $\begin{array}{l}\text { Rex W. Tillerson } \\
\text { Benvan Beurden }\end{array}$ & Exxon Mc & 05.10.2019 & https:///corporate.exxonmobili.com/News/Newsroom/speeches/ \\
\hline 08.06.2015 & $\begin{array}{l}\text { Ben van Beurden } \\
\text { Bob Dudley }\end{array}$ & Shell & 28.01 .2019 & https://www.shell.com/media/speeches-and-articles/2015/innovating-our-way-to-a-sustainable-future.html \\
\hline 26.06 .2015 & Alexucy Miller & Gazprom & 05.10.2019 & 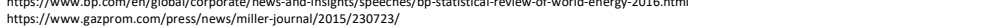 \\
\hline 01.09 .2015 & Alexey Miller & Gazprom & 05.10 .2019 & https:///www.gazprom.com//ress/news//miller-journal/2015/245685/ \\
\hline 0.2015 & $\begin{array}{l}\text { Rex W. Tillerson } \\
\text { Ben van Beurden }\end{array}$ & $\begin{array}{l}\text { Exxon Mobil } \\
\text { Shell }\end{array}$ & 05.10 .2019 & https://corporate.eexonmobili.com/News/Newsroom/speeches/2015/1001_Securing-Growth-through-Sound-Energy-Policy \\
\hline 06.10 .2015 & $\begin{array}{l}\text { Ben van Beurden } \\
\text { Rex W. Tillerson }\end{array}$ & $\begin{array}{l}\text { Shell } \\
\text { Exxon Mobil }\end{array}$ & $\begin{array}{l}28.01 .2019 \\
05.102019\end{array}$ & 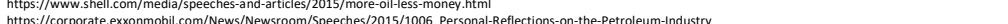 \\
\hline 06.10.2015 & $\begin{array}{l}\text { Rex W. Tulerson } \\
\text { Alexey Miller }\end{array}$ & $\begin{array}{l}\text { Exxon Mobil } \\
\text { Gazprom }\end{array}$ & $\begin{array}{l}05.10 .2019 \\
05.10 .2019\end{array}$ & 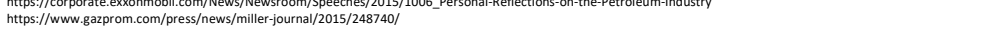 \\
\hline 07.10 .2015 & Rex W. Tillerson & Exxon Mobil & 05.10 .2019 & https://corporate.exxonmobili.com/News/Newsroom/Speeches/2015/1007_Unleashing-Inovation-To-Meet-our-Energy-and-Environmental-Needs \\
\hline $\begin{array}{l}03.11 .2015 \\
06.11 .2015\end{array}$ & $\begin{array}{l}\text { Rex W. Tillerson } \\
\text { Ben van Beurden }\end{array}$ & $\begin{array}{l}\text { Exxon Mobil } \\
\text { Shell }\end{array}$ & $\begin{array}{l}05.10 .2019 \\
28.012019\end{array}$ & 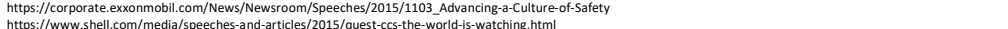 \\
\hline 13.11.2015 & Amin H. Nasser & Saudi & 28.01 .2019 & https://wweb.archive.org/web/20160415004249//ttp://www.saudiaramco.com/en/home/news-media/speeches/detroit-AHN.html \\
\hline 01.12.2015 & Amin H. Nasser & Saudi & 28.01.2019 & \\
\hline 25.12.2015 & & Aramco & 28.01.2019 & https://webarchhive.org/web/201608191414636//ttp:///saudiaramco.com/en/home/news-media//speeches//KTVA-Launch.html \\
\hline 10.02 .2016 & $\begin{array}{l}\text { Alexey Miner } \\
\text { Bob Dudley }\end{array}$ & $\begin{array}{l}\text { Gapprom } \\
\text { BP }\end{array}$ & $\begin{array}{l}05.10 .2019 \\
06.102019\end{array}$ & 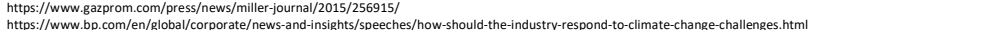 \\
\hline & Bob Dudley & & 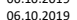 & 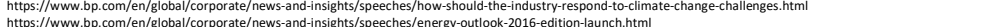 \\
\hline 02.03.2016 & Ben van Beurden & Shell & 28.01 .2019 & 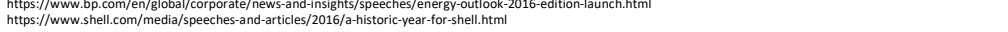 \\
\hline 21.03.2016 & Amin H. Nasser & Saudi & 28.01.2019 & https://web.archive.org/web/20160811110105/http://saudiaramco.com/n/home/news-media/speeches/establishing-a-new-body-of-industry-and-new-growth-drivers.html \\
\hline 12.04.2016 & Ben van Beurden & $\begin{array}{l}\text { Aramci } \\
\text { Shell }\end{array}$ & 28.01.2019 & https://www.shell.com/media/speeches-and-articles/2016/a-time-for-lng.html \\
\hline 4.2016 & Bob Dudley & BP & 06.10 .2019 & https://www.bp.com/en/global/corporate/news-and-insights/speeches/2016-annual-general-meeting-group-chief-executive.html \\
\hline 2016 & Bob Dudley & & 06.10 .2019 & https://www.bp.com/en/global/corporate/news-and-insights/speeches/the-paris-climate-agreement-and-the-future-of-fossil-fuels.html \\
\hline 2016 & $\begin{array}{l}\text { Rex w. Therson } \\
\text { Rexw. Tillerson }\end{array}$ & $\begin{array}{l}\text { Exxon Mobil } \\
\text { Exxon Mobil }\end{array}$ & $\begin{array}{l}05.10 .2019 \\
05.102019\end{array}$ & 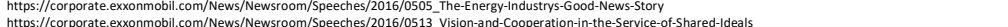 \\
\hline 2016 & Ben van Beurden & Shell & 28.01 .2019 & 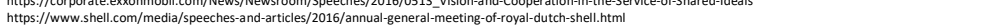 \\
\hline 1016 & Alexey Miller & Gazprom & 05.10 .2019 & \\
\hline 23.06.2 & Bob Dudley & BP & 06.10 .2019 & https://www.bp.com/en/global/corporate/news-and-insights/speeches/the-economic-club-of-washington-dc. \\
\hline & Ben van Beurden & & 28.01.2019 & https://www.shell.com/media/speeches-and-articles/2016/power-of-questions.html \\
\hline 30.06.2016 & Alexey Miller & Gazprom & 05.10 .2019 & https://www.gazprom.com/press/news/miller-journal/2016/277935/ \\
\hline 20.07.2016 & Amin H. Nasser & $\begin{array}{l}\text { Saudi } \\
\text { Aramco }\end{array}$ & 28.01.2019 & https://web.archive.org/web/20170707052026/http://saudiaramco.com/en/home/news-media/speeches/fachili-gas-program.html \\
\hline $\begin{array}{l}29.08 .2016 \\
330802016\end{array}$ & $\begin{array}{l}\text { Ben van Beurden } \\
\text { Alexey Miller }\end{array}$ & $\begin{array}{l}\text { Shell } \\
\text { Gazprom }\end{array}$ & $\begin{array}{l}28.01 .2019 \\
0.102019\end{array}$ & $\begin{array}{l}\text { https://www.shell.com/media/speeches-and-articles/2016/energy-transition-being-the-contrarian-in-the-room.html } \\
\text { htro./Wwy }\end{array}$ \\
\hline 26.09.2016 & Amin H. Nasser & Saudi & 28.01 .2019 & https://web.archive.org/web/20170707023046/http://saudiaramco.com/en/home/news-media/speeches/ep20-a-new-business-model-for-a-new-era.html \\
\hline 26092016 - & Amin $H_{\text {N Nasser }}$ & & 28012019 & 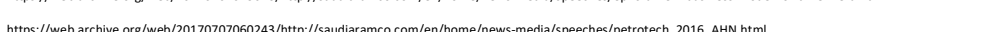 \\
\hline 26.09 .2016 & Amin H. Nasser & Aramco & 28.01.2019 & https://web.archive.org/web/20170707060243/http://saudiaramco.com/en/home/news-media/speeches/petrotech_2016_AHN.html \\
\hline 04.10.2016 & Alexey Miller & Gazprom & 05.10.2019 & https://www.gazprom.com/press/news/miller-journal/2016/287880/ \\
\hline 11.10.2016 & Amin H. Nasser & $\begin{array}{l}\text { Sadi } \\
\text { Aramco }\end{array}$ & 05.12 .2018 & https://www.saudiaramco.com/en/news-media/speeches/2016/world-energy-congress-wec-2016 \\
\hline $\begin{array}{l}11.10 .2016 \\
18.10 .2016\end{array}$ & $\begin{array}{l}\text { Bob Dudley } \\
\text { Bob Dudley }\end{array}$ & $\begin{array}{ll}\mathrm{BP} \\
\mathrm{BP}\end{array}$ & $\begin{array}{l}06.10 .2019 \\
06.10 .2019\end{array}$ & $\begin{array}{l}\text { https://www.bp.com/en/global/corporate/news-and-insights/speeches/world-energy-congress.html } \\
\text { https://www.bp.com/en//global/corporate/news-and-insights/speeches/competitiveness-carbon-choice-embracing-change.html }\end{array}$ \\
\hline & & Exxon Mobil & 05.10 .2019 & https://corporate.eexxonmobiliccom/News/Newsroom/Speeches/2016/1019_The-Path-Forward-in-Todays-Energy-Environment \\
\hline 01.11 .2016 & Amin H. Nasser & $\begin{array}{l}\text { Saudi } \\
\text { Aramco }\end{array}$ & 28.01.2019 & https://web.archive.org/web/20170707061354//http://saudiaramco.com/en/home/news-media/speeches/kapsarc-energy-dialogue.html \\
\hline 04.11.2016 & Bob Dudley & & 06.10 .2019 & ittps://www.bp.com/en/global/corporate/news-and-insights/speeches/the-oil-and-gas-cl| \\
\hline & & obil & & \\
\hline & Bob Dudley & Saudi & 06.10.2019 & (e \\
\hline 08.12.2016 & Amin H. Nasser & & 05.12.2018 & https://www.saudiaramco.com/nn/news-media/speches/2016//ikva-2016-keynote-nasser \\
\hline 22.12.2016 & Amin H. Nasser & $\begin{array}{l}\text { Saudi } \\
\text { Aramco }\end{array}$ & 05.12 .2018 & https://www.saudiaramco.com/en/news-media/speeches/2016/jwwith-pertamina \\
\hline 30.12 .2016 & $\begin{array}{l}\text { Alexey Miller } \\
\text { Bob Dudley }\end{array}$ & Gazprom & & ( \\
\hline $\begin{array}{l}25.01 .2017 \\
08.02 .2017\end{array}$ & $\begin{array}{l}\text { Bob Dudley } \\
\text { Ben van Beurden }\end{array}$ & $\begin{array}{l}\text { SP } \\
\text { Shell }\end{array}$ & $\begin{array}{l}00.101 .2019 \\
28.01 .2019\end{array}$ & 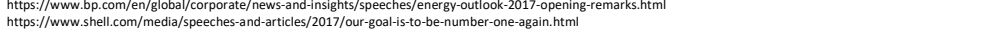 \\
\hline 28.02.2017 & Amin H. Nasser & $\begin{array}{l}\text { Saudi } \\
\text { Aramco }\end{array}$ & 05.12.2018 & https://www.saudiaramco.com/en/news-media/speeches/2017/refining-chemicals-complex-agreement-petronas \\
\hline 06.03.2017 & & Exxon Mobil & 05.10 .2019 & https://corporate.exxonmobili.com/News/Newsroom/speeches/2017/0306_CERA-week-keynote-speech \\
\hline 09.03.2. & Benvan Beu & & 1.2019 & I//www.shell.com/media/speeches-and-articles/2017/deliver-today-prepare-for-tomorrow.html \\
\hline 22.03.2017 & Ben van Beurden & & 28.01.2019 & https://www.shell.com/media/speeches-and-articles/2017/three-keys-to-successful-global-energy-transition.html \\
\hline 27.04.2017 & Amin H. Nasser & $\begin{array}{l}\text { Saudi } \\
\text { Aramco }\end{array}$ & 05.12 .2018 & https://www.saudiaramco.com/en/news-media/speeches/2017/paris-oil-summit-2017 \\
\hline & & & & neral-meeting-group-chief-executive.html \\
\hline & $\begin{array}{l}\text { Ben van Beurden } \\
\text { Alexey Miller }\end{array}$ & & & 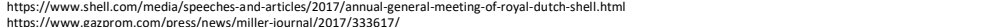 \\
\hline 01.06 .2017 & & Gapprom & 05.10 .2019 & 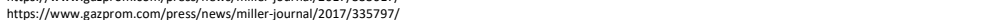 \\
\hline
\end{tabular}




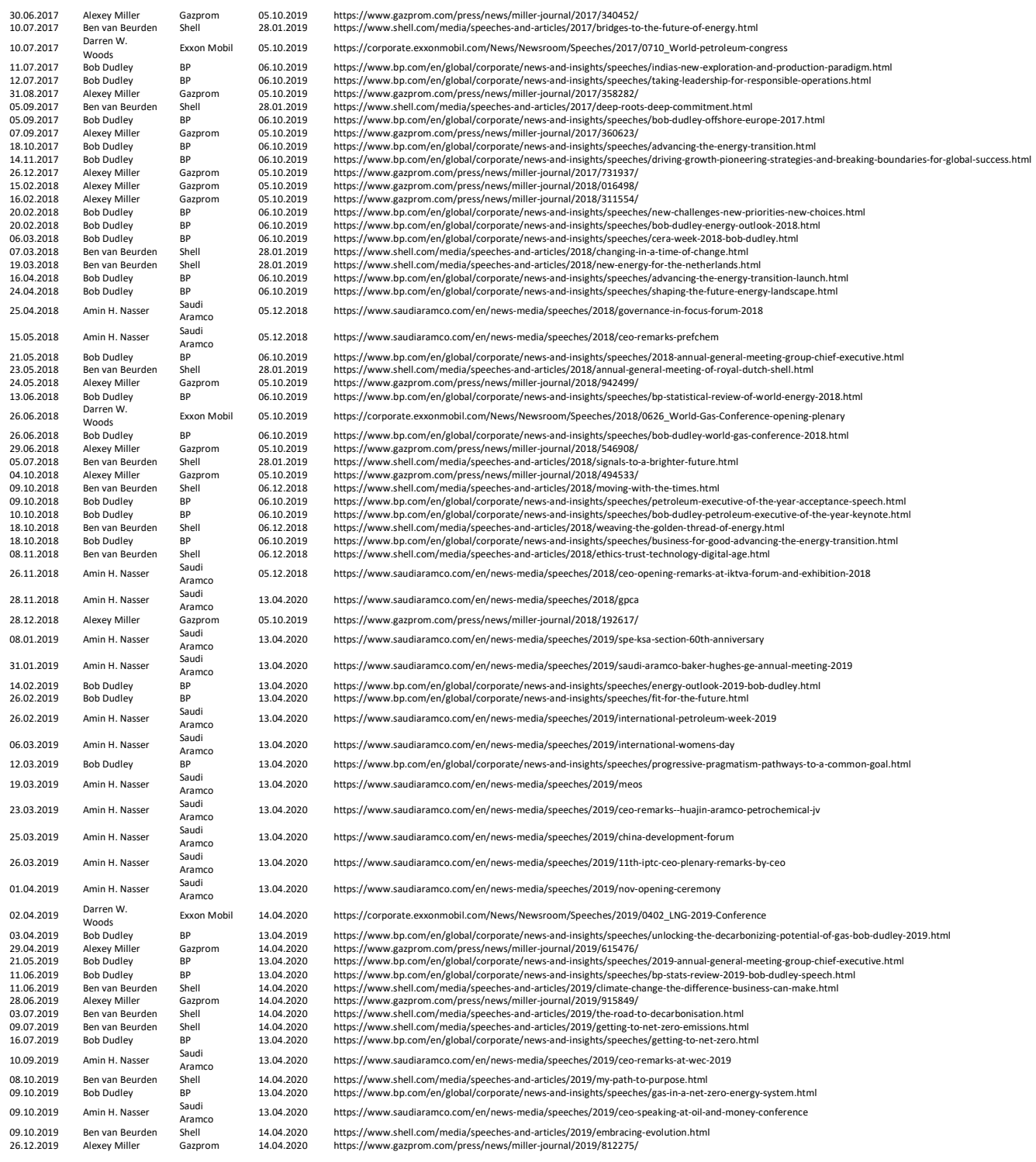

